\title{
Deep-sea nematode assemblage has not recovered 26 years after experimental mining of polymetallic nodules (Clarion-Clipperton Fracture Zone, Tropical Eastern Pacific)
}

\author{
Dmitry M. Miljutin ${ }^{\mathbf{a}, *}$, Maria A. Miljutina ${ }^{\mathbf{a}}$, Pedro Martínez Arbizuª ${ }^{\mathbf{a}}$ Joëlle Galéron ${ }^{\mathbf{b}}$
}

\footnotetext{
a Senckenberg am Meer, Deutsches Zentrum für Marine Biodiversitätsforschung, Südstrand 44, 26382 Wilhelmshaven, Germany

${ }^{\mathrm{b}}$ Institut Français de Recherche pour l'Exploitation de la MER, Département Étude des Écosystèmes Profonds, Centre de Brest BP 70, 29280 Plouzané, France
}

\author{
*: Corresponding author : Dmitry M. Miljutin : Tel.: +49 44219475124 ; fax: +49 44219475111 \\ email address :Dmitry.Miljutin@senckenberg.de ; miljutin@yahoo.com
}

\begin{abstract}
:
We investigated nematode assemblages inhabiting the 26-year-old track created by experimental deep-sea mining of polymetallic nodules, and two adjacent, undisturbed sites, one with nodules and one without nodules. The aim was to compare density, assemblage structure, and diversity indices in order to assess the process of recovery of the nematode assemblage inhabiting the disturbed site. This experimental dredging was conducted in 1978 by the Ocean Minerals Company (USA) in the area of a French mining claim in the Clarion-Clipperton Fracture Zone (Tropical Eastern Pacific) at a depth of about $5000 \mathrm{~m}$. The nematode assemblage had not returned its initial state 26 years after the experimental dredging: the total nematode density and biomass within the dredging track were significantly lower than outside the track; the biodiversity indices showed significantly lower nematode diversity within the track; and the structure of the nematode assemblage within the track differed significantly from those in the two undisturbed sites outside the track. However, there were no significant differences in the mean body volumes of adult nematodes and adult-juvenile ratios between the track and reference sites. Parameters such as the rate of sediment restoration (which depends on local hydrological conditions) and the degree and character of the disturbance appeared to be of considerable importance for the recovery rate of the deep-sea nematode assemblages and their ability to recolonize disturbed areas. The rates of recolonization and recovery may vary widely in different deep-sea regions.
\end{abstract}

\section{Highlights}

Nematode assemblages from mining track and adjacent undisturbed sites were compared. This 26-year-old track resulted from the mining of deep-sea polymetallic nodules. $>$ The nematode assemblage inhabiting the track showed lower diversity and density. The assemblage composition in the track also differed from that in the undisturbed sites.

Keywords : Body volume ; Deep-sea ; Density ; Disturbance ; Diversity ; Dredging ; Mining ; Nematode ; Nodule ; Recolonization ; Recovery 


\section{Introduction}

Marine polymetallic nodules are considered a potential resource for some commercially important metals, such as $\mathrm{Mn}, \mathrm{Ni}, \mathrm{Cu}$, and Co (Mero, 1965; Halbach et al., 1975; Morgan, 2000). As a rule, the nodules cover the surface of the sea floor or are embedded in the upper 5-10 cm layer of the bottom sediments. Their individual diameter and their abundance can reach 15-20 cm and several tens of kilograms per $1 \mathrm{~m} 2$, respectively (Du Castel, 1985; Hoffert, 2008). Fields of polymetallic nodules are now known from different areas of the World Ocean (Cronan, 2001). The most commercially attractive deposits are concentrated in the Northeastern Tropical Pacific, in the so-called "manganese nodule province" situated between the Clarion and the Clipperton Fracture Zones (Clarion-Clipperton Fracture Zone, or CCFZ) at depths of 4,000-5,000 m (Halbach et al., 1975; Mero, 1977). This region is about 5 million km2, and it has been estimated that 5-10 billion tons of nodules could be recovered from the estimated 30 billion tons that occur there (Baker et al., 2001).

Deep-sea mining of polymetallic nodules is predicted to begin within two or more decades (Thiel et al., 2005). Commercial mining is presently unprofitable because of the high cost and technological complexity of this process. However, because of the great potential importance of this resource, the International Seabed Authority (ISA) was established in 1994. The ISA is in charge of activities in ocean areas beyond the limits of national jurisdictions, with the aim of managing resources (http://www.isa.org.jm/en/home; Thiel et al., 2001; Hoffert, 2008). Thiel et al. (1991) estimate that the economic requirement for profitable mining is about 1.5 million dry tons of nodules per year for a minimum 20-year period. This means that about $1 \mathrm{~km} 2$ of sea floor will be mined daily, or about $6,000 \mathrm{~km} 2$ over the 20-year life of a mine site. According to Glover and Smith (2003), nodule mining could annually disrupt sea-floor communities over areas of 1,200 to $12,000 \mathrm{~km} 2$, and 15 years of such mining could conceivably impact $180,000 \mathrm{~km} 2$ of sea floor. Thus, the vast deep-sea seafloor will be seriously disturbed during the mining operations.

In spite of the remote prospect of commercial mining, experimental mining of nodules has been successfully carried out in several localities. The techniques devised for the extraction of nodules from the sea bottom employ mechanical screening, bucket, or scraper methods, or hydraulic approaches to lift the nodules from the sea floor; probably both will be combined (Thiel, 2003). These techniques will lead to the complete destruction of the upper $5-10 \mathrm{~cm}$ layer of soft sediments and the removal of nodules, which are dispersed in the upper sediment layer. Most of meiobenthic organisms (i.e. metazoan animals living on the surface or within sediments and passing through a sieve with $1 \mathrm{~mm}$ mesh size but retained by a 40 !m mesh) inhabit the upper 0-5 cm layer of deep-sea sediments (see, e.g., Snider et al., 1984; Vanreusel et al., 1995b), and they will inevitably be disturbed or killed during the mining.

Chung et al. (2002) summarized the potential impacts on the benthic fauna during the mining: 1) direct impact along the track of the nodule collector, where the sediment and associated fauna is crushed or dispersed in a plume, and the nodules are removed, 2) smothering 
or entombment of the benthic fauna by the sediment plume, and 3) destruction of food resources of some species. The nodules themselves are a specific habitat for some organisms inhabiting their surface and the interstitial space inside their crevices and internal cavities (Thiel et al., 1993; Veillette et al., 2007a,b). Thus, in addition to the destruction and dispersal of the upper soft-sediment layer, the nodule-associated fauna will also be lost during mining.

Before commercial mining begins, studies must be conducted to evaluate the possible impact on the sea floor and living communities. First, we should estimate the proportion of biological diversity that will be destroyed by deep-sea mining (Thiel et al., 2005). Several previous studies of the recovery rate of deep-sea meiobenthos after an experimental disturbance have been conducted in nodule fields in five distant areas of the deep ocean. The initial stage of all these studies was a simulation of nodule mining, and then, after several years, the comparison of living communities from the impacted site and adjacent undisturbed sites. The Disturbance and Recolonization Experiment (DISCOL) was started in 1989 in the Peru Basin (South Pacific), and the repeat study was carried out 7 years later (Thiel, 1992; Borowski and Thiel, 1998; Borowski, 2001; Ahnert and Schriever, 2001; Thiel et al., 2001; Vopel and Thiel, 2001). In 1994, the Japan Deep-sea Impact Experiment (JET) was initiated in the western CCFZ and the study site resampled 1 and 2 years later (Barnett and Yamauchi, 1995; Fukushima, 1995; Kaneko et al., 1997; Shirayama, 1999; Shirayama et al., 2001). The third study was the Inter Ocean Metal Benthic Impact Experiment (IOM BIE) in the eastern CCFZ, initiated in 1995 with resampling conducted 2 years later (Brockett, 1994; Radziejewska et al., 2001a,b; Radziejewska, 2002). The Indian Deep-sea Environment Experiment (INDEX) in the Central Indian Basin (Indian Ocean) investigated total meiofaunal density 4 years after the disturbance was carried out in 1997 (Sharma, 2001; Ingole et al., 1999; 2001; Ingole et al., 2005). Finally, the species composition of harpacticoids within and outside the track 26 years after the experimental nodule dredging by the American consortium OMCO (Ocean Minerals Company) (conducted in 1978 in the CCFZ) was recently studied by Mahatma (2009). 
Among benthic animals, the meiobenthos possesses numerous advantages for studying

the response of living assemblages to disturbance because of their widespread occurrence, high availability and diversity, short living cycle, and the relative ease with which they can be sampled quantitatively. In the above mentioned experiments, the community composition, density, and diversity of higher taxa (in majority of the experiments), harpacticoid genera and families (DISCOL, IOM BIE), and nematode genera and families (DISCOL, IOM BIE), were studied. The species diversity and the total density of harpacticoids were reported to be recovered 26 years after the OMCO dredging, whereas the assemblage composition at the species level still differed from that at the undisturbed site (Mahatma 2009). In the IOM BIE experiment, the genus-level harpacticoid assemblage composition had nearly recovered 2 years after the disturbance, whereas the nematode assemblage composition and diversity had not (Radziejewska, 2001a,b). The sediment characteristics and total nematode density within the track did not differ from those at the adjacent intact site after 2 years. In the DISCOL project, the sediment characteristics within the track was not restored after 7 years. The nematode assemblage composition at genus level recovered in this experiment, but the diversity and the total density were significantly lower (Vopel and Thiel, 2001). Moreover, the nematofauna inhabiting the surface and crevices of nodules differed from the nematode assemblages in the surrounding soft sediments with respect to the composition of dominants; some species of nematodes were found only in nodule crevices (Bussau, 1993; Thiel et al., 1993; Bussau et al., 1995). The total harpacticoid density at the DISCOL site recovered 7 years after the disturbance, although there was still a significant difference in harpacticoid assemblage composition at the family level between the disturbed and adjacent undisturbed sites (Ahnert and Schriever 2001). In the JET experiment, the total abundance of harpacticoids significantly increased during the year after the disturbance (Kaneko et al., 1997), whereas the total meiofauna density was lower in the disturbed area 4 years after the disturbance in the INDEX experiment (Ingole et al., 2005). The results of these experiments, therefore, are ambiguous and differ depending on the 
experiment and the meiobenthic group and taxonomic level examined. However, in general, the harpacticoid assemblages recovered more completely than nematode assemblages.

In the present study, we investigated the nematode assemblages inhabiting the 26-yearold track created by deep-sea experimental nodule dredging, and adjacent intact, undisturbed sites. This experimental mining was conducted by the American consortium OMCO (Ocean Minerals Company) in 1978, in the area of the French mining claim in the CCFZ. The nematode assemblage from the track was compared with the nematode assemblage from the surrounding nodule-bearing site (i.e. assemblages from disturbed and undisturbed areas with initial identical environmental conditions) and with the nematode assemblages from the neighbouring nodulefree site for comparison between the nodule-free track and a pristine nodule-free area. The nematode assemblages from the undisturbed nodule-bearing and nodule-free sites were previously described in detail by Miljutina et al. (2010). In the present paper, these data were used again in order to compare them with nematode assemblages from the track. The main hypothesis is that there were no differences in density, assemblage composition, and diversity between the track and surrounding undisturbed sites.

\section{Materials and methods}

\subsection{Study area and background}

The study area $\left(\approx 14^{\circ} \mathrm{N}, 130^{\circ} \mathrm{W}\right)$ is in the easternmost part of the French mining claim in the CCFZ (Fig. 1A) at an average depth of about $5000 \mathrm{~m}$. The bottom is covered by ferromanganese nodules with an average of $\sim 12 \mathrm{~kg} / \mathrm{m}^{2}$ of (Du Castel, 1985; Hoffert, 2008). A more detailed description is given by Miljutina et al. (2010).

In 1978, a dredge aboard the MV "Hughes Glomar Explorer", operated by OMCO, made a mining track at a depth of about 5000 meters in the nodule field of the French mining claim within the CCFZ. A self-propelled test miner equipped with Archimedean screws was used. The 
nodules were collected and lifted on board using a lift-pipe system, and the soft sediment was released into the water column (Chung, 2005). This dredging operation left behind a track ca. 1.5 $\mathrm{m}$ wide, and skimmed the upper layer of sediments to a depth of ca. $4.5 \mathrm{~cm}$ (Khripounoff et al., 2006).

Khripounoff et al. (2006) studied the environmental differences between the track and adjacent intact areas after 26 years. They noted that, because of the very low sedimentation rate and mean bottom current speed (see above), the physical and chemical parameters (water content, nitrogen, $\mathrm{Si}, \mathrm{Al}, \mathrm{Fe}, \mathrm{K}, \mathrm{Mg}$ ) of the disturbed seafloor and the surface layer of sediment did not change significantly over time and have not shown any recovery since the disturbance. The track appears as though it had just been made (Fig. 1). Meanwhile, 26 years after the dredge's passage, there was no statistically significant difference between the track and the surrounding sediments in the concentrations of $\mathrm{O}_{2}$, main nutrients (silicates, nitrates, phosphates), and the rate of total oxygen consumption by the biota. However, the concentration of organic carbon in the $0-1-\mathrm{cm}$ sediment layer in the track was about $30 \%$ higher than at the neighboring intact site.

\subsection{Data sampling}

The material was collected during the scientific cruise NODINAUT (RV "L'Atalante", IFREMER, equipped with the submersible 'Nautile'; chief scientist J. Galéron), in the French mining claims of the CCFZ in June 2004. The samples were obtained at three different sites: (1) an area with nodules (nodule-bearing site, NB site), (2) an area without nodules ("non-nodule" site, NN site) and (3) within the 26-year-old track created by the experimental mining (T site) (Fig. 2). In the NB and NN sites, quantitative and qualitative samples were taken using an 8tube-multicorer (tube diameter $100 \mathrm{~mm})$ and a USNEL corer $(0.5 \mathrm{~m} \times 0.5 \mathrm{~m})$, deployed from the ship. Within the track, a blade corer $(20 \times 9 \mathrm{~cm})$ operated from the "Nautile" was used (Table 1). 
The upper $5 \mathrm{~cm}$ of cores was used for quantitative studies. All samples were initially fixed on board with $4 \%$ buffered formaldehyde solution in seawater.

\subsection{Material processing}

Meiobenthic organisms were separated from sediments using Levasil@-kaolin medium with triple centrifugation at $4000 \mathrm{rpm}$ for 6 min (McIntyre and Warwick, 1984). A 40- $\mu \mathrm{m}$-mesh sieve was used to concentrate the animals. About 100 nematodes were picked out randomly from each sample using a Bogorov counting chamber. Nematodes were processed in glycerin, by means of Seinhorst's method of slow evaporation (Seinhorst, 1959), and permanently mounted on glycerin-paraffin slides. Nematodes were then initially identified under the light microscope to family and genus levels (where possible) using the guides for genera of British free-living nematodes (Platt and Warwick, 1983, 1988; Warwick et al., 1998), together with the NeMys web database (Deprez et al., 2005) and other publications. Then the nematodes were sorted to putative species (morphotypes), each of which was drawn with the aid of a drawing tube in order to compare all specimens of the same genus. In total, 750,1186 , and 582 individual nematodes were investigated from the NB, NN, and T sites respectively. The nematode identifications were entered into an MS ACCESS database.

The approximate internal body volume of adult nematodes was calculated from the formula of Feller and Warwick (1988). For the calculation of body volumes, one or several adult individuals belonging to each morphotype were measured (only morphotypes represented by adults were used for this calculation). The resulting body measurements were considered to represent the mean values for the respective morphotype. In total, 367 adult individuals from the NB site, 470 from the NN site, and 270 from the $\mathrm{T}$ site, belonging to 195 morphotypes and comprising $73 \%$ of all sorted adult specimens, were used to calculate the mean individual body volumes for $\mathrm{NB}, \mathrm{NN}$, and $\mathrm{T}$ sites. 
The adult-juvenile ratios of all morphotypes were calculated for each sample and the average ratio for each of the three sites determined.

\subsection{Statistical analysis}

The software packages PAST (Hummer et al., 2001) and PRIMER v6 (Clarke and Gorley, 2006) were used for statistical analysis. Nematode diversity at family, genus, and species level was measured using Margalef's ( $d$, indicates a taxon richness in assemblages), Pielou's (J', indicates evenness), $\log _{2}$-based Shannon's $\left(H^{\prime}\right.$, indicates a weighted evenness) indices, and estimated species, genus, and family richness for the sample of 51 specimens (SR [51], GR [51], and $F R[51]$, respectively). In addition, average taxonomic diversity $(\Delta)$ and average taxonomic distinctness $(\Delta *)$ indices, which measure the relatedness of species within assemblages (Warwick and Clarke, 1995), were calculated. Non-metric multidimensional scaling (nMDS) plots and the analyses of similarity (ANOSIM) were based on both Bray-Curtis and Cosine similarity distances (no transformations, standardized data matrix). The Bray-Curtis similarity distance is the most commonly used metric in meiobenthic research. The Cosine similarity distance was chosen because of its invariance with respect to the magnitude of species abundance (Jackson, 1993), as a substantial number of morphotypes were represented by a single individual in our data. The similarity percentage (SIMPER) option based on Bray-Curtis similarity distance was used for assessing which taxa were primarily responsible for an observed difference between groups of samples. Student's $t$-test was used to test the significances of differences between univariative values (all compared values were log-normalized).

\subsection{Assessment of appropriateness to compare samples from the track and from the nodule field}

The track stations are quite distant from the stations established at the undisturbed sites (Fig. 2). The nearest "nodule" station (located on the undisturbed nodule site) is $1012 \mathrm{~m}$ away 
from the track. The maximum distance from the track to the "nodule" stations is $3764 \mathrm{~m}$, and the

mean distance is $2050 \mathrm{~m}$. Thus, the question arises, whether it is statistically appropriate to compare the samples from the track and from the nodule field. The fauna of the track may differ from the fauna of the "nodule" stations merely because of their spatial separation. The fauna of the track may differ from the fauna of the "nodule" stations merely because of their spatial separation. The track stations are located approximately at the same distance from the "nodule" stations, as the latter are from each other (from 199 to $3867 \mathrm{~m}, 2094$ on average). We assume that there is no relationship between the studied ecological parameters (a composite of nematode assemblages, total nematode density, diversity indices) and the distance between the "nodule" stations and their spatial arrangement. If this 'H1 hypothesis' (no correlation exists) is not rejected, then the nodule field can be considered as a space with a homogeneous nematode assemblage and distribution. In this case, any differences between nematode assemblages from the track and surrounded intact nodule site can be explained by the influence of dredging.

Nematode taxa (at species, genus, and family levels) whose relative abundance in samples was correlated with the distance between sampling points were searched using the BEST procedure (PRIMER v6). This procedure selects those taxa for which the relative abundance is best correlated with the spatial pattern of sampling (Clarke and Warwick, 2001; Clarke et al., 2008). The list may consist of one or many taxa, the combination of which gives the highest correlation coefficient. The resemblance matrix of Euclidean distances between samples was generated using normalized coordinates of samples. The nematode relative abundances were square-root-transformed. The correlation between the composition of the nematode assemblages and the spatial arrangement of the "nodule" samples was also tested, using the BEST analysis. The correlation between the total nematode density and biodiversity indices (all log-normalized) of "nodule" samples and the spatial arrangement of "nodule" samples was tested using the PAST software (the Pearson's $r$ correlation coefficient was 
evaluated). The normalized latitude and longitude (in decimal degrees) of each "nodule" station were tested as environmental parameters.

\section{Results}

\subsection{Appropriateness of comparing samples from the track and from the nodule field}

The BEST procedure selected some lists of nematode taxa for which the relative abundances had the highest correlations with the sampling pattern in the NB site. However, the significance level of the $H_{0}$ hypothesis (no correlation exists) was more than $5 \%$ (Table 2), so it was not rejected. The same result (non-rejected $H_{0}$ hypothesis) was obtained when correlations between the coordinates of stations and the total density of nematodes in samples from the NB site and their different diversity indices were tested (Table 3). We concluded, therefore, there were no relationships between any of these tested ecological parameters and the sampling pattern in the NB site. The NB site can therefore be considered as a space with a homogenous nematode assemblage. The dredging track was located within this homogenous space, and can be assumed to have had the same nematode assemblage characteristics as the surrounding area before it was disturbed. Any differences in the characteristics of the nematode assemblages between the $\mathrm{T}$ and NB sites therefore can be explained by the influence of the dredging.

\subsection{Nematode body volume and adult-juvenile ratio}

The mean weighted body volume of adult specimens at the NN and T sites $(0.79 \mathrm{nl}$ and $0.80 \mathrm{nl}$, respectively) were higher than at the $\mathrm{NB}$ site $(0.71 \mathrm{nl})$, but this difference was statistically insignificant (the minimum $p$-level was 0.376 ), according to the pairwise $t$-test (Fig. $3 \mathrm{~A})$. The adult-juvenile ratios at the $\mathrm{NB}, \mathrm{NN}$, and $\mathrm{T}$ sites were $1.47,1.32$, and 1.19 , respectively (Fig. 3B). The difference between sites was statistically insignificant (the minimum $p$-level was 0.111 ), according to the pairwise $t$-test. 


\subsection{Nematode density}

According to the pairwise Student's $t$-test (significance level for the $H_{0}$ hypothesis < 0.0001 for both tested pairs, $\mathrm{T}$ vs. NN and T vs. NB), the mean nematode density in the samples from the track $\left(30.7\right.$ inds $/ 10 \mathrm{~cm}^{2}$ ) was significantly lower than in surrounding intact areas, including the NB and NN sites (69.5 and 136.9 inds $/ 10 \mathrm{~cm}^{2}$ respectively) (Fig. 4).

\subsection{Nematode assemblages}

In total, 138 nematode species representing 50 genera and 24 families were found within the track (Table 4). The two most specious genera were Thalassomonhystera (24 species among 198 specimens) and Acantholaimus (10 species among 40 specimens). The species richness of Acantholaimus within the track was lower than at the NB and NN sites, where species richness normalized to 40 specimens (ES(40)) was 13.8 and 13.9 respectively. The $E S(40)$ values for the genus Thalassomonhystera were 13.6, 14.1, and 11.2 for the track, NB site, and NN site respectively. Thus, the species richness of Thalassomonhystera within the track was approximately equal to or even higher than at the undisturbed sites. The nematode species assemblage from the $\mathrm{T}$ site was more even in comparison with the $\mathrm{NB}$ and $\mathrm{NN}$ sites (Fig. 5). Four subdominant species (relative abundance more than 5\%) were found at the $\mathrm{T}$ site (Table 5).

Monhysteridae, Xyalidae, Chromadoridae, and Oncholaimidae were the most abundant families at the $\mathrm{T}$ site (Table 5). Thalassomonhystera ranked first among genera $(34.4 \%$ of all nematode specimens) (Table 5). Theristus, Oncholaimus, and Acantholaimus were subdominants. Among species, Theristus discolensis was the most abundant at the $\mathrm{T}$ site, followed by Oncholaimus sp. 3, which was almost equally abundant.

The pair-wise ANOSIM test revealed that the nematode assemblage at the T site differed significantly from the nematode assemblages at the NB and NN sites at species, genus, and 
family levels (Table 6). In the nMDS graphs constructed according to both Bray-Curtis and Cosine similarities (Fig. 6), the samples from the T site are grouped apart from the NB and NN samples.

According to the SIMPER test, the largest contribution to dissimilarity between the $\mathrm{T}$ site and the surrounding intact NB and NN sites at species level was made by Oncholaimus sp. 3, Thalassomonhystera sp. 19, and Thalassomonhystera sp. 25, which were quite abundant at the T site and very rare at the intact sites (Table 7). At the genus level, the largest dissimilarity was caused by higher relative abundances of the genera Thalassomonhystera and Oncholaimus, and a smaller relative abundance of the genus Acantholaimus, at the T site.

\subsection{Biodiversity assessment}

At species, genus, and family levels, biodiversity and taxonomic indices for the nematode assemblage from the $\mathrm{T}$ site were significantly lower than for those from the NB and NN sites, except for the Margalef's index at family level (Tables 8, 9; Figs 7, 8). The rarefaction curve, which shows the estimated number of species for a specified number of individuals, also suggests that species richness at the $\mathrm{T}$ site was significantly lower than at the NB and the NN sites (Fig. 9).

\section{Discussion}

\subsection{Abiotic conditions and disturbance methods}

In our experiment, the dredging operation profoundly changed the benthic environment along the track; nodules were removed together with the upper $4.5 \mathrm{~cm}$-deep layer of soft sediments (Khripounoff et al., 2006). The seafloor did not recover after the dredging because of the low sedimentation rate and the absence of near-bottom currents. However, the concentrations of nutrients (silicates, nitrates, phosphates) and oxygen, as well as the rate of total oxygen 
consumption (presumably indicating total biological metabolism) in the track sediment, did not differ from the surrounding undisturbed sediments, and seemed to have been restored (Khripounoff et al., 2006). Two other remarkable differences were observed. First, the porewater content in the uppermost sediment layer $(0-0.5 \mathrm{~cm})$ was lower than at the undisturbed reference site, and was similar to the pore-water content at a depth of $4.5 \mathrm{~cm}$ in the undisturbed sediment. The upper sediment layer in the track was therefore denser than at surrounding intact sites. In other words, the uppermost 5-cm-thick sediment layer was removed during the mining, and, 26 years later, the new $0-5-\mathrm{cm}$ layer still preserves the compactness that it had when it was at a depth of $\sim 5-10 \mathrm{~cm}$. Probably the granulometric composition of the removed superficial sediment layer also differed from the underlying sediment (as was noted during the INDEX experiment, described by Valsangkar, 2005), although there are no data about the composition of this layer.

The second difference was that the concentration of organic carbon in the $0-1-\mathrm{cm}$ sediment layer in the track was about $30 \%$ higher than at the neighboring intact site. A possible explanation is that organic remains sinking from the water column could concentrate in a shallow hollow, such as that formed by the track.

In contrast to the present study, the DISCOL and IOM BIE experiments employed disturbance methods that did not involve the extraction of nodules. In the DISCOL experiment, the sediments were disturbed but not removed. This treatment led to an increase in habitat heterogeneity and total nematode density (Vopel and Thiel, 2001). In the IOM BIE experiment, the sediment was released into the water column, but nodules were not extracted. It is also important to note that strong near-bottom current apparently existed in the area of the IOM BIE, since the track was almost invisible and covered with fresh sediments 2 years after the disturber's passage. In the DISCOL experiment, however, the track appeared only slightly fuzzy 7 years after the disturbance. To sum up, there were two main differences in these experiments: a 
"lighter" method of disturbance used during DISCOL, and strong near-bottom currents that helped to restore the sediment structure in the IOM BIE area (Table 10).

\subsection{Nematode individual body volume, biomass, and density}

The mean individual body volumes of adult nematodes and the adult-juvenile ratios showed no significant differences between the sites. Therefore, in both cases, the total nematode density may reflect correctly the total nematode biomass (Fig. 4). Evidently, the total nematode biomass was also significantly lower at the T site compared to the NB and NN sites. In contrast, Vanaverbecke et al. (2003) found that smaller nematodes predominated in a shallow-water, periodically disturbed area. However, this area was frequently disturbed, whereas the seafloor within the track was disturbed only once, 26 years ago. From this point of view, the nematode assemblage of the track may be considered as mature and established. Our data do not corroborate the positive relationship between the individual nematode body size or weight (which depend directly on body volume) and food availability reported in many other studies (e.g., Soetaert and Heip, 1989; Vanreusel et al., 1995a; Soltwedel et al., 1996). In our case, the higher values of organic carbon within the track (Khripounoff et al., 2006) did not influence the mean individual body volume of adult nematodes. However, the enrichment by organic carbon within the track was only about $30 \%$ higher than in the surrounding sites and only in the upper 0-1 cm layer. Possibly, the method used to calculate the mean nematode body volumes was insufficiently accurate to reveal the trend seen in the above mentioned studies.

The total nematode density was significantly lower in the track: less than half that at the nodule-bearing NB site, and less than a quarter of that at the nodule-free NN site. As suggested earlier by Miljutina et al. (2010), the lower density at the NB site compared to the NN site may be related to the presence of nodules, which reduced the volume in the samples of fine-grained sediment inhabited by meiobenthic organisms. The lower nematode density in the track (no 
nodules) than at the NB site (nodules present) may reflect the removal of the superficial layer of sediments during the dredging. In the abyss, about $70-90 \%$ of the nematodes inhabit the upper 1-2 cm layer of sediments (Snider et al., 1984; Bussau, 1993; Vanreusel et al., 1995b). In our track samples, the surficial sediment layer, which would have been inhabited by a dense nematode population, was removed. The new superficial $(0-5 \mathrm{~cm})$ layer still preserved the characteristics of deeper sediment, i.e. the 5-10 cm layer that it occupied before the dredging operation. This may explain why the total nematode density of the $0-5 \mathrm{~cm}$ sediment layer within the track was lower than at the reference sites. The nematode density was also lower than in the DISCOL reference area 7 years after the disturbance, but similar to that in the reference area 2 years after the disturbance in the IOM BIE experiment (Table 10). Possibly, the DISCOL track had not returned to its pre-disturbance condition, whereas the IOM BIE track had.

\subsection{Nematode assemblage structure and diversity}

Chromadoridae, Monhysteridae, and Xyalidae were the most abundant families at all three sites (Miljutina et al., 2010; Table 5), but the order of dominance was different. At the NB site, Chromadoridae and Monhysteridae were the first top-ranked families, with almost equal percentages, members of Xyalidae were the most abundant at the NN site, and members of Monhysteridae at the $\mathrm{T}$ site. Oncholaimidae were very rare in the intact areas (Miljutina et al., 2010), whereas they ranked fourth at the $T$ site.

At the genus level, Thalassomonhystera ranked first at all sites (Miljutina et al., 2010; Table 5) with Acantholaimus and Theristus in second and third places. However, Acantholaimus was the second most abundant genus at both the undisturbed sites (NB and NN), whereas Theristus was ranked second at the T site. Oncholaimus, the other subdominant genus at the T site, was very rare at NB and NN..

Assemblages at the two undisturbed sites were similar at the species level; in both cases Theristus discolensis and Thalassomonhystera sp. 3 were the dominant species (Miljutina et al., 
2010). At the $\mathrm{T}$ site, T. discolensis was also the most abundant species, whereas

Thalassomonhystera sp. 3 was only ranked fifth, with Oncholaimus sp. 3 in second place. It is interesting that Oncholaimus sp. 3 was entirely absent at the NB site, and rare (average abundance $0.3 \%$ ) at the NN site (Table 5). Other species, which ranked between $3^{\text {rd }}$ and $8^{\text {th }}$ at the T site, also did not enter the top ten of the NB and NN sites (Miljutina, 2010). The nematode species assemblage from the $\mathrm{T}$ site was characterized by four subdominant species compared with only one at the NB and NN sites (Table 5; Fig. 5).

The most notable difference between the nematode assemblages in the track and the adjacent undisturbed sites was that Oncholaimus sp. 3 was one of the most abundant species in the former but very rare in the latter. Other Oncholaimus species showed a similar pattern.. Species of the family Oncholaimidae can be very abundant in organically and chemically polluted littoral and shallow-water sediments (Lorenzen et al., 1987; Bett and Moore, 1988; Warwick and Robinson, 2000; Fadeeva et al., 2003; Pavlyuk et al., 2005). Some oncholaimids (including some species of the genus Oncholaimus) were classified by Moens and Vincx (1997) mainly as facultative predators that consume other nematodes, but they can also feed on detritus and dead nematodes. Also, O. paraolium was dominant in a species-poor, low-density nematode assemblage in a littoral area subjected to recurrent riverine influence (Pavlyuk et al., 2007). Oncholaimus was one of the two dominant genera in the tidal zone exposed to impacts from icescouring and concomitant salinity fluctuations (Urban-Malinga et al., 2005). Two other oncholaimid species, Meyersia sp. and Metaparoncholaimus sp., both facultative predators, were common in a harbor environment affected by heavy organic input (Sougawa et al., 2008). Thus, oncholaimids seem to have a propensity to dominate in organic-rich, disturbed biotopes. Compared with the adjacent area, the sediment organic content was higher within the track, which may explain the higher proportion of oncholaimids here. In the DISCOL experiment, oncholaimids were quite rare in both the disturbed and undisturbed areas $(0.8 \%$ and $0.2 \%$ 
respectively) (Vopel and Tiel, 2001). They were not mentioned at all in connection with the IOM BIE experiment (Radziejewska et al., 2001a) and were, evidently, very rare there.

The genus Acantholaimus (one of the most abundant genera in the study area) was much less abundant and less species-rich in the track compared to the undisturbed sites (Miljtunia et al., 2010). This may be connected to the higher content of organic carbon in the $0-1 \mathrm{~cm}$ layer in the track. A significant negative correspondence between the chlorophyll $a$ content in sediments and the relative abundance and diversity of the genus Acantholaimus in nematode assemblages was observed in an earlier study (De Mesel et al., 2006). The chlorophyll $a$ value indirectly indicates the organic-matter content (namely, the flux of phytoplankton remains) in the sediment. It therefore seems likely that Acantholaimus is less well adapted to organic-rich habitats than other nematode species. Acantholaimus was reported to be the most abundant genus in both the track and the reference area in the DISCOL experiment (Vopel and Thiel, 2001). The "lighter" disturbance method used during DISCOL may account for the difference in the response of this genus to disturbance in the present study and DISCOL (see 4.1).

The nematode diversity within the track (measured with biodiversity and taxonomic indices) was significantly lower than at the NB and NN sites (Tables 8, 9; Figs 7, 8), whereas there was no significant difference between the NB and the NN sites at all taxonomic levels (Table 11; Miljutina et al., 2010). This may reflect the fact that the removal of the upper sediment layer by the dredge brought nematodes inhabiting the lower layer (where their diversity was lower) to the sediment surface. At the same time, the recolonization of the track by nematodes from the surrounding undisturbed sediment may have been inhibited by the lessfavorable environment provided by this newly-exposed deeper sediment layer. Nematode diversity at the genus level was also lower than in the reference areas in both the DISCOL and IOM BIE experiments. The nematode assemblage generic composition within tracks differed significantly from the reference area in the IOM BIE experiment, but showed no significant difference from the reference area in the DISCOL experiment (Table 10). 


\subsection{Comparison of nematode recovery rate with recovery rates of other meiobenthic groups}

As noted in the Introduction, harpacticoid assemblages recovered better than nematodes in earlier deep-sea disturbance experiments. Among deep-sea meiobenthic taxa, harpacticoids are probably the most flexible group, and, after a disturbance, they usually recolonize and recover more easily and rapidly than the nematodes. This is also true for shallow-water harpacticoids and nematodes (Fonsêca-Genevois et al., 2006; Giere, 2009). Thus, the recovery rate of deep-sea meiobenthic taxa after a physical disturbance depends on their behavioral flexibility and greater dispersal capabilities. The other important factors are the rate of sediment restoration (which can depend strongly on local hydrological conditions) and the degree and intensity of the disturbance.

It is interesting, that the total density of meiofauna recovered to the pre-disturbance level in four of the five deep-sea disturbance experiments (the OMCO dredging, DISCOL, IOM BIE, and JET) (Schirayama, 1999; Ahnert and Schriever, 2001; Radziejewska et al., 2001a,b; Radziejewska, 2002; Mahatma, 2009). There were also no differences in meiofaunal diversity and community structure at the level of major taxa 26 years after the OMCO dredging (Mahatma, 2009). The total meiofaunal density was still reduced, 4 years after the disturbance, only in the INDEX experiment (Ingole et al., 2005). This suggests that the analysis of major taxa is not sufficiently sensitive to reveal changes in meiobenthic communities.

\subsection{Possible factors influencing the recovery rate of nematode assemblages}

The 26-year period was not sufficient for the nematode assemblage to re-establish its former density, diversity, and structure. The capacity of nematodes to recolonize disturbed biotopes depends on several main factors. The presence of near-bottom currents hastens the introduction of nematodes into disturbed areas from adjacent sediments. In addition, the 
transport of sediment into the dredged area from surrounding sites speeds the restoration of the

sediment structure, thereby facilitating the recolonization process. However, near-bottom currents were virtually absent in the track area. The speed of recolonization also depends on the physiological or behavioral characteristics of species and their reproductive strategies (K- or rstrategy). Because of their smaller body size in comparison to shallow-water nematodes, the lower water temperature and lower organic-matter input in deep water compared to shallow water, deep-sea nematodes seem to be less able to reproduce quickly than their shallow-water counterparts; for example, they reach sexual maturity more slowly, and produce fewer eggs that need more time to mature. They may be mainly persisters rather than colonizers.

Experiments suggest that physical disturbance may exert more influence on nematode assemblage structure and density than organic enrichment (Austen and Widdicombe, 2006). Schratzberger and Warwick (1998) showed that nematodes inhabiting muddy sediments are more sensitive to physical disturbance than those living on sandy bottoms. It seems, therefore, that the sediment characteristics in the track were more important for nematode assemblage recovery than other parameters (concentrations of organic matter and other nutrients, oxygen). This may explain why the total nematode density and diversity in the track were lower, despite the fact that the organic-carbon content in the upper sediment layer was even higher than at the undisturbed site.

Numerous studies have shown that, in the intertidal and shallow-water zones, nematode assemblages usually require 1 to $50-80$ days to recover after physical disturbance (see, e.g., Sherman and Coull, 1980; Colangelo and Ceccherelli, 1994; Schratzberger and Warwick, 1998; Peck et al., 1999; Lee et al., 2001a,b; Johnson et al., 2007). Because of frequent or even permanent natural disturbance in this zone, the fauna is well adapted to the resulting stress (Lee et al., 2001b). In addition, coastal currents and high sedimentation rates facilitate the recolonization of near-shore areas. However, except at vents and other ephermeral habitats, the abyss is much more stable than the intertidal zone. Deep-sea regions may be quiescent over a 
period of many years, allowing the benthic community to reach a fine competitive equilibrium.

After a disturbance, the equilibrium between species is unbalanced. In this case, species that are most efficient at exploiting resources under the new environmental conditions may eliminate other species. Even if all species have equal competitive ability, some may be better adapted to post-disturbance environments and will proliferate more quickly (Connel, 1978). If the environment returns to its pre-disturbance condition slowly (as in the present study), the original living community may never be re-established. This process may also lead to a decrease in diversity until a new competitive equilibrium is obtained (Connel, 1978).

The nodule-mining operation therefore may lead to significant changes in meiobenthic communities. These communities may require quite long recovery periods, more than several decades according to the present study; indeed, it is not clear whether they will ever return to the pre-disturbance condition. Disturbance experiments have impacted only very small parts of the nodule fields, but in the case of full-scale commercial mining, vast areas (millions of square kilometers) will be damaged. After the long rehabilitation period, when the species composition of the meiobenthic community will be modified over a vast area, some species may be lost permanently. Since the meiobenthos represents a basic level in the food chain for larger animals, changes in meiobenthic communities may also lead to changes in macrobenthic and megabenthic communities.

\section{Acknowledgements}

The authors thank the captain and the crew of RV "l'Atalante" and the submersible "Nautile" team for their skilled help in sampling the material during the NODINAUT cruise, and Dr. Radith Mahatma (Riau University, Indonesia) for his help in the treatment of samples. The first and second authors express their gratitude to CeDAMar and CoML for the financial support of their investigation. The authors also thank Dr. Janet W. Reid, (JWR Associates, USA) and Prof. Dr. Andrew J. Gooday (National Oceanography Centre, Southampton, UK), for their 
critical revision of the English text, and also Dr. Daria Portnova (P.P.Shirshov Institute of Oceanology, Moscow, Russia) and the other, anonymous reviewer for their valuable remarks. 


\section{References}

Ahnert, A., Schriever, G. 2001. Response of abyssal Copepoda Harpacticoida (Crustacea) and other meiobenthos to an artificial disturbance and its bearing on future mining for polymetallic nodules. Deep-Sea Res. II 48, 3779-3794.

Austen, M.C., Widdicombe S., 2006. Comparison of the response of meio- and macrobenthos to disturbance and organic enrichment. J. Exp. Mar. Biol. Ecol. 330, 96-104.

Baker, C.M., Bett, B.J., Billett, D.S.M., Rogers, A.D., 2001. An environmental perspective. In: WWF/IUCN (Eds.), The status of natural resources on the high-seas. WWF/IUCN, Gland, Switzerland, pp. 1-68.

Barnett, U., Yamauchi, H., 1995. Deep sea sediment resuspension system used for the Japan Deep Sea Impact Experiment. Proc. I Ocean Mining Symp. (Tsukubo, Japan, November 21-22), 175-179.Bett, B.J., Moor, K.G., 1988. The taxonomy and biology of a new species Pontonema (Nematoda, Oncholaimidae) dominant in organically polluted sublittoral sediments around Scotland, with a review of the genus. J. Nat. Hist. 22, 13631377.

Borowski, C., 2001. Physically disturbed deep-sea macrofauna in the Peru Basin, southeast Pacific, revisited 7 years after the experimental impact. Deep-Sea Res. II 48, 3809-3839.

Borowski, C., Thiel, H., 1998. Dee-sea macrofaunal impact of a large-scale physical disturbance experiment in the Southeast Pacific. Deep-Sea Res. II 45, 55-81.

Brockett, T., 1994. Deepsea mining simulator for environmental impact studies. Sea Technol. 35, $78-82$.

Bussau, C., 1993. Taxonomische und ökologische Untersuchungen an Nematoden des PeruBeckens. PhD thesis, Christian-Albrechts-Universität zu Kiel, 621 pp.

Bussau, C., Schriever, G., Thiel, H., 1995. Evaluation of abyssal metazoan meiofauna from a manganese nodule area of the Eastern South Pacific. Vie et Milieu 45(1), 39-48. 
Chung, J.S., 2005. Deep-ocean Mining Technology: Development II. Proc. 64th ISOPE Ocean Mining Symp. (Changsha, Hunan, China, October 9-13), 1-6.

Chung, J.S., Schriever, G., Sharma, R., Yamazaki, T., 2002. Deep seabed mining environment: preliminary engineering and environmental assessment. ISOPE Special Report OMSEN-1, 19 pp.

Clarke, K.R., Gorley, R.N., 2006. PRIMER v6: User Manual/Tutorial. PRIMER-E, Plymouth, 91 pp.

Clarke, K.R., Warwick, R.M., 2001. Change in marine communities: an approach to statistical analysis and interpretation. 2nd edition. PRIMER-E Ltd., Plymouth. 174 pp.

Clarke, K.R., Somerfield, P.J., Gorley, R.N., 2008. Testing of null hypotheses in exploratory community analyses: similarity profiles and biota-environment linkage. J. Exp. Mar. Biol. Ecol. 366, 56-69.

Colangelo, M.A., Ceccherelli, V.U., 1994. Meiofaunal recolonization of azoic sediment in a Po Delta lagoon (Sacca di Goro). Boll. Zool. 61, 335-342.

Connel, J.H., 1978. Diversity in tropical rain forests and coral reefs. Science, New Series 199, $1302-1310$.

Cronan, D.S., 2001. Manganese Nodules. In: Turekian, K., Thorpe, S. (Eds.), Encyclopedia of Ocean Sciences. San Diego Academic Press, pp. 1526-1533.

De Mesel, I.D., Lee, H.J., Vanhove, S., Vincx, M., Vanreusel, A., 2006. Species diversity and distribution within the deep-sea nematode genus Acantholaimus on the continental shelf and slope in Antarctica. Polar Biol. 29, 860-871.

Deprez, T. et al., 2005. NeMys. World Wide Web electronic publication. www.nemys.ugent.be, version $(12 / 2010)$

Du Castel, V., 1985. Etablissement d'une carte géologique au 1/20 000 d'un domaine océanique profond dans une zone riche en nodules polymétalliques du Pacifique Nord (zone 
Clarion-Clipperton). Thèse de doctorat, Université de Bretagne Occidentale (Brest), 259 pp.

Fadeeva, N.P., Bezverbnaja, I.P., Tazaki, K., Watanabe, H., Fadeev, V.I., 2003. Composition and structure of marine benthic community regarding conditions of chronic harbour pollution. Ocean and Polar Res. 25(1), 21-30.

Feller, R.J., Warwick, R.M., 1988. Energetics. In: Higgins, R.P., Thiel, H. (Eds) Introdiction to the study of meiofauna. Smithsonian Institution Press, Washington DC, pp. 181-196.

Fukushima, T., 1995. Overview - Japan Deep-Sea Impact Experiment - JET. Proc. I Ocean Mining Symp. (Tsukubo, Japan, November 21-22), pp. 47-53.

Gareth, E.L., Johnson, G.E.L., Martin, J., Attrill, M.J., Emma, V., Sheehan, E.V., Somerfield, P.G., 2007. Recovery of meiofauna communities following mudflat disturbance by trampling associated with crab-tiling. Mar. Env. Res. 64(4). 409-416.

Glover, A.G., Smith, C.R., 2003. The deep-sea floor ecosystem: current status and prospects of anthropogenic change by the year 2025. Environ. Conserv. 30(3), 219-241.

Halbach, P., Özkara, M., Hense, J., 1975. The influence of metal content on the physical and mineralogical properties of pelagic manganese nodules. Miner. Deposita 10, 397-411.

Hammer, Ø., Harper, D.A.T., Ryan, P.D., 2001. PAST: Paleontological Statistics Software Package for Education and Data Analysis. Palaeontol. Electron. 4(1), 9 pp. Http://palaeoelectronica.org/2001_1/past/issue1_01.htm.

Hoffert, M., 2008. Les nodules polymétalliques dans les grands fonds océaniques. Une extraordinaire aventure minière et scientifique sous-marine. Société Géologique de France Vuibert, $431 \mathrm{pp}$.

Ingole, B.S., Ansari, Z.A., Matondkar, S.G.P., Rodriges, N., 1999. Immediate response of meio and macrobenthos to disturbance caused by a benthic disturber. Proc. III Ocean Mining Symp. (Goa, India, November 8-10), pp. 191-194. 
Ingole, B.S., Ansari, Z.A., Rathod, V., Rodriges, N., 2001. Response of deep-sea macrobenthos to a small-scale environmental disturbance. Deep-Sea Res. II 48, 3401-3410.

Jackson, D.A., 1993 Multivariate analysis of benthic invertebrate communities: the implication of choosing particular data standardizations, measures of association, and ordination methods. Hydrobiologia 268, 9-26.

Johnson, G.E.L., Attrill, M.J., Sheehan, E.V., Somerfield, P.J., 2007. Recovery of meiofauna communities following mudflat disturbance by trampling associated with crab-tiling. Mar. Environ. Res. 64, 409-416.

Kaneko, T., Maejima, Y., Teishima, H., 1997. The abundance and vertical distribution of abyssal benthic fauna in the japan deep-sea impact experiment. Proc. VII Ocean Mining Symp. (Honolulu, USA, May 25-30), pp. 475-479.

Khripounoff, A., Caprais, J.-C., Crassous, Ph., 2006. Geochemical and biological recovery of the disturbed seafloor in polymetallic nodule fields of the Clipperton-Clarion Fracture Zone (CCFZ) at 5,000-m depth. Limnol. Oceanogr. 51(5), 2033-2041.

Lee, H., Gerdes, D., Vanhove, S., Vincx, M., 2001a. Meiofauna response to iceberg disturbance on the Antarctic continental shelf at Kapp Norvegia (Weddell Sea). Polar Biol. 24(12), 926-933.

Lee, H., Vanhove, S., Peck, L.S., Vincx, M., 2001b. Recolonization of meiofauna after catastrophic iceberg scouring in shallow Antarctic sediments. Polar Biol. 24(12), 918925.

Lorencen, S., Prein, M., Valentin, C., 1987. Mass aggregations of the free-living marine nematode Pontonema vulgare (Oncholaimidae) in organically polluted fjords. Mar. Ecol. Prog. Ser. 37, 27-34.

Mahatma, R., 2009. Meiofauna communities of the Pacific Nodule Province: abundance, diversity and community structure. $\mathrm{PhD}$ thesis, Carl von Ossietzky Universität, Oldenburg, 142 pp. 
McIntyre, A.D., Warwick, R.M., 1984. Meiofauna techniques. In: Holme, N.A., McIntyre, A.D. (Eds.), Methods for the Study of Marine Benthos. Blackwell Scientific Publishers, Oxford, pp. 217-244.

Mero, J.L., 1965. The mineral resources of the sea. Elsevier, Amsterdam, 312 pp.

Mero, J.L., 1977. Economic aspects of nodule mining. In: Glasby, G.P. (Ed.), Marine Manganese Deposits. Elsevier Oceanography Series 15, Elsevier Scientific Publishing Company, Amsterdam, pp. 327-355.

Miljutina, M.A., Miljutin, D.M., Mahatma, R., Galéron, J., 2010. Deep sea nematode assemblages of the Clarion-Clipperton Nodule Province (Tropical North-Eastern Pacific). Mar. Biodiv. 40, 1-15.

Moens, T., Vincx, M., 1997. Observations on the feeding ecology of estuarine nematodes. J. Mar. Biol. Ass. UK 77, 211-227.

Morgan, C.L., 2000. Resources estimates of the Clarion-Clipperton manganese nodule deposits. In: Cronan, D.S. (Ed.), Handbook of Marine Mineral Deposits, CRC Press, pp. 145-170.

Pavlyuk, O.N., Trebukhova, J.A., Chernova, E.N., 2005. The meiobenthos in the area of Japanese scallop cultivation in Minonosok Bay (Peter the Great Bay, Sea of Japan). Russ. J. Mar. Biol. 31(5), 279-287.

Pavlyuk, O.N., Trebukhova, J.A., Belogurova, L.S., 2007. Effect of the Razdol'naya River on structure of the free-living nematode community of the Amursky Bay, Sea of Japan. Russ. J. Mar. Biol. 33(4), 213-221.

Peck, L.S., Brockington, S., Vanhove, S., Beghyn, M., 1999. Community recovery following catastrophic iceberg impacts in a soft-sediment shallow-water site at Signy Island, Antarctica. Mar. Ecol. Prog. Ser. 186, 1-8.

Platt, H.M., Warwick, R.M., 1983. Free-living marine nematodes. In: Part I. Kermack, D.M., Barnes, R.S.K. (Eds.), British enoplids. Synopses of the British Fauna (New series) 28, Cambridge University Press, 307 pp. 
Platt, H.M., Warwick, R.M., 1988. Free-living marine nematodes. In: Part II. Kermack, D.M., Barnes, R.S.K. (Eds.), British chromadorids. Synopses of the British Fauna (New series), 38, E. J. Brill and Dr. W. Backhuys Press, 502 pp.

Radziejewska, T., 2002. Responses of deep-sea meiobenthic communities to sediment disturbance simulating effects of polymetallic nodule mining. Internat. Rev. Hydrobiol. $87(4), 457-477$.

Radziejewska, T., Drzycimski, I., Galtsova, V.V., Kulangieva, L.V., 2001a. Changes in genuslevel diversity of meiobenthic free-living nematodes (Nematoda) and harpacticoids (Copepoda Harpacticoida) at an abyssal site following experimental sediment disturbance. Proc. IV Ocean Mining Symp. (Szczecin, Poland, September 23-27, 2001), $38-43$.

Radziejewska, T., Rokicka-Praxmajer, J., Stoyanova, V., 2001b. IOM BIE revisited: meiobenthos at the IOM BIE site 5 years after the experimental disturbance. Proc. 4th Ocean Mining Symp. (Szczecin, Poland, September 23-27), 63-68.

Schratzberger, M., Warwick, R.M., 1998. Effects of physical disturbance on nematode communities in sand and mud: a microcosm experiment. Mar. Biol. 130, 643-650.

Seinhorst, J.W., 1959. A rapid method for the transfer of nematodes from fixative to anhydrous glycerin. Nematologica 4, 67-69.

Sharma, R., 2001. Indian deep-sea environmental experiment (INDEX): an appraisal. Deep-Sea Res. II 48, 3295-3307.

Sherman, K.M., Coull, B.C., 1980. The response of meiofauna to sediment disturbance. J. Exp. Mar. Biol. Ecol. 46, 59-71.

Shirayama, Y., 1999. Biological results of the JET project: an overview. Proc. III Ocean Mining Symp. (Goa, India, November 8-10), 185-188. 
Shirayama, Y., Fukushima, T., Matsui, T., Kuboki, E., 2001. The responses of deep-sea benthic organisms to experimental removal of the surface sediment. Proc. IV Ocean Mining Symp. (Szczecin, Poland, September 23-27), 77-81.

Snider, L.G., Burnett, B.R., Hessler, R.R., 1984. The composition and distribution of meiofauna and nanobiota in central North Pacific deep-sea area. Deep-Sea Res. 31, 1225-1249.

Soetaert, K., Heip, C., 1989. The size structure ofnematode assemblages along a Mediterranenan deep-sea transect. Deep-Sea Res. 36, 93-102.

Sougawa, H., Shimode, S., Hashimoto, T., Kikuchi, T., 2008. Potential use of meiobenthos and free-living nematodes for sediment quality assessment in Manazuru Port, Sagami Bay, Japan. Jpn. J. Benthol. 63, 11-22.

Soltwedel, T., Pfannkuche, O., Thiel., H., 1996. The size structure of deep-sea meiobenthos in the North-Eastern Atlantic: nematode size spectra in relation to environmental variables. J. Mar. Biol. Ass. UK 76, 327-344.

Thiel, H., 1991. From MESEDA to DISCOL: a new approach to deep-sea mining risk assessment. Mar. Min. 10(4), 369-386.

Thiel, H., 1992. Deep-sea environmental disturbance and recovery potential. Int. Rev. Hydrobiol. $77(2), 331-339$.

Thiel. H., 2003. Anthropogenic impacts on the deep sea. In: Tyler, P.A. (Ed.), Ecosystems of the deep oceans. Elsevier, Amsterdam, pp. 427-472.

Thiel, H., Foell, E., Schriever, G., 1991. Potential environmental effects of deep sea mining. Report Nr. 26, Zentrum für Meeres- und Klimaforschung der Universität Hamburg, 243 pp.

Thiel, H., Schriever, G., Bussau, C., Borowsky, C., 1993. Manganese nodule crevice fauna. Deep-Sea Res. I 40(2), 419-423. 
Thiel, H., Schriever, G., Ahnert, A., Bluhm, H., Borowski, C., Vopel, K., 2001. The large-scale environmental impact experiment DISCOL - reflection and foresight. Deep-Sea Res. II 48, 3869-3882.

Thiel, H., Schriever, G., Foell, E.J., 2005. Polymetallic nodule mining, waste disposal and species extinction at the abyssal floor. Mar. Georesour. Geotechnol. 23, 209-220.

Urban-Malinga, B., Wiktor, J., Jabłońska, A., Moens, T., 2005. Intertidal meiofauna of a highlatitude glacial Arctic fjord (Konigsfjorden, Svalbard) with emphasis on the structure of free-living nematode communities. Polar Biol. 28, 940-950.

Vanaverbeke, J., Steyaert, M, Vanreusel, A., Vincx, M., 2003. Nematode biomass spectra as descriptors of functional changes due to human and natural impact. Mar. Ecol. Prog. Ser. 249, 157-170.Valsangkar, A.B., 2005. First phase monitoring studies of simulated benthic disturbance experiment delineating movement of fine particles in the Central Indian Basin. Mar. Georesour. Geotechnol. 23, 357-371.

Vanreusel, A., Vincx, M., Bett, B.J., Rice, A.L., 1995a. Nematode biomass spectra at two abyssal sites in the NE Atlantic with a contrusting food supply. Int. Rev. Hydrobiol. 80(2), 287-296.

Vanreusel, A., Vincx, M., Schram, D., Van Gansbeke, D., 1995b. On the vertical distribution of the metazoan meiofauna in shelf break and upper slope habitats of the NE Atlantic. Int. Rev. Hydrobiol. 80(2), 313-326.

Veillette, J., Sarrazin, J., Gooday, A.J., Galéron, J., Caprais, J.-C., Vangreisheim, A., Étoubleau, J., Christian, J.R., Juniper, S.K., 2007a. Ferromanganese nodule fauna in the Tropical North Pacific Ocean: species richness, faunal cover and spatial distribution. Deep-Sea Res. I 54(11), 1912-1935.

Veillette, J., Juniper, S.K., Gooday, A.J., Sarrazin, J., 2007b. Influence of surface texture and microhabitat heterogeneity in structuring nodule faunal communities. Deep-Sea Res. I 54(11), 1936-1943. 
Vopel, K., Thiel, H., 2001. Abyssal nematode assemblages in physically disturbed and adjacent sites of the eastern equatorial Pacific. Deep-Sea Res. II 48, 3795-3808.

Warwick, R.M., Clarke, K.R., 1995. New 'biodiversity’ measures reveal a decrease in taxonomic distinctness with increasing stress. Mar. Ecol. Prog. Ser. 129, 301-305.

Warwick, R.M., Platt, H.M., Somerfield, P.J., 1998. Free-living marine nematodes. In: Part III. Barnes, R.S.K., Crothers, J.H. (Eds.), Monhysterids. Synopses of the British Fauna (New series) 53, Field Studies Council Press, 296 pp.

Warwick, R.M., Robinson, J., 2000. Sibling species in the marine pollution indicator genus Pontonema Leidy (Nematoda: Oncholaimidae), with a description of P. mediterranea sp. nov. J. Nat. Hist. 34, 641-662. 


\section{FIGURE LEGENDS}

Fig. 1. Photograph of 26-year-old track, taken in 2004 from the submersible "Nautile".

Fig. 2. Study area. A: location of sampling area (marked with a square); B: detailed map of sampling area.

Fig. 3. Weighted individual body volumes (in $\mathrm{nl}$ ) of adult nematodes (A) and ratios of adults to juveniles (B). Abbreviations: NB: nodule site; NN: nodule-free site; T: 26-year-old track.

Fig. 4. Total nematode density (individuals per $10 \mathrm{~cm}^{2}$ ) for the nodule site (NB), the nodule-free site $(\mathrm{NN})$, and the 26-year-old dredging track (T).

Fig. 5. Cumulative dominance curves for the nodule field, the nodule-free field, and the 26-yearold dredging track at species level.

Fig. 6. The nMDS plots (based on both Bray-Curtis and Cosine similarity) for nematode assemblages at species, genus, and family levels. Relative abundances were used, without transformation. A, B: species level; C, D: genus level; E, F: family level.

Fig. 7. Nematode diversity indices (mean, $\pm 2 \mathrm{SE}$, max, and min) at levels of species, genus, and family for the nodule site (NB), the nodule-free site (NN), and the 26-year-old dredging $\operatorname{track}(\mathrm{T})$.

Fig. 8. Average taxonomic diversity $(\Delta)$ and average taxonomic distinctness $(\Delta *)$ indices (mean, $\pm 2 \mathrm{SE}$, max, and min) for the nodule site (NB), the nodule-free site (NN), and the 26year-old dredging track $(\mathrm{T})$.

Fig. 9. Rarefaction curves (number of species per number of individuals examined) for the nodule-free site $(\mathrm{NN})$, the nodule-bearing site (NB), and the 26-year-old track (T). Grey fields indicate $95 \%$ confidence intervals. 
Table 1. Collecting devices, station locations, dates, and number of nematodes examined for cores collected for nematofaunal analysis. Abbreviations: $\mathrm{NB}=$ nodule-bearing site; $\mathrm{NN}=$ site outside nodule field; $\mathrm{T}=$ track; $\mathrm{MUC}=$ multicorer; $\mathrm{UC}=\mathrm{USNEL}$ corer; $\mathrm{BC}=$ blade corer.

\begin{tabular}{|c|c|c|c|c|c|c|c|c|}
\hline Device & Station & Cores & Date & $\begin{array}{l}\text { Latitude } \\
(\mathrm{N})\end{array}$ & $\begin{array}{l}\text { Longitude } \\
\text { (W) }\end{array}$ & $\begin{array}{l}\text { Depth } \\
\text { (m) }\end{array}$ & Site & $\begin{array}{c}\text { Number of individuals } \\
\text { examined in cores }\end{array}$ \\
\hline MUC* & MTB-1 & 2 & 26.05 .2004 & $14^{\circ} 03.98^{\prime}$ & $130^{\circ} 06.96^{\prime}$ & 4,983 & NB & 97 \\
\hline MUC & MTB-14 & 5 & 31.05 .2004 & $14^{\circ} 03.08^{\prime}$ & $130^{\circ} 08.55^{\prime}$ & 4,877 & NB & _** \\
\hline MUC & MTB-15 & $1 ; 2$ & 03.06 .2004 & $14^{\circ} 02.69^{\prime}$ & $130^{\circ} 07.84^{\prime}$ & 4,947 & NB & $80 ; 85$ \\
\hline MUC & MTB-16 & $3 ; 4$ & 03.06 .2004 & $14^{\circ} 02.70^{\prime}$ & $130^{\circ} 07.73^{\prime}$ & 4,950 & NB & $91 ; 88$ \\
\hline MUC & MTB-18 & $2 ; 3 ; 7$ & 07.06 .2004 & $14^{\circ} 02.52^{\prime}$ & $130^{\circ} 07.98^{\prime}$ & 4,950 & NB & $81 ; 115 ; 106$ \\
\hline MUC & MTB-17 & 6 & 07.06 .2004 & $14^{\circ} 02.20^{\prime}$ & $130^{\circ} 06.60^{\prime}$ & 5,000 & NB & 104 \\
\hline $\mathrm{UC}^{*}$ & KGS-6 & - & 28.05 .2004 & $14^{\circ} 03.01^{\prime}$ & $130^{\circ} 06.93^{\prime}$ & 4,974 & NB & 68 \\
\hline MUC* & MTB-2 & - & 27.05 .2004 & $14^{\circ} 03.40^{\prime}$ & $130^{\circ} 05.58^{\prime}$ & 5,013 & $\mathrm{NN}$ & 81 \\
\hline MUC* & MTB-3 & - & 28.05 .2004 & $14^{\circ} 02.74^{\prime}$ & $130^{\circ} 05.11^{\prime}$ & 5,046 & $\mathrm{NN}$ & 98 \\
\hline MUC & MTB-6 & $2 ; 3$ & 30.05 .2004 & $14^{\circ} 02.86^{\prime}$ & $130^{\circ} 05.35^{\prime}$ & 5,040 & $\mathrm{NN}$ & $92 ; 95$ \\
\hline MUC & MTB-7 & $6 ; 7$ & 30.05 .2004 & $14^{\circ} 02.88^{\prime}$ & $130^{\circ} 04.97^{\prime}$ & 5,042 & $\mathrm{NN}$ & $86 ; 95$ \\
\hline MUC & MTB-8 & $2 ; 4$ & 31.05 .2004 & $14^{\circ} 02.55^{\prime}$ & $130^{\circ} 05.35^{\prime}$ & 5,035 & $\mathrm{NN}$ & $78 ; 94$ \\
\hline MUC & MTB-10 & 8 & 01.06 .2004 & $14^{\circ} 02.80^{\prime}$ & $130^{\circ} 05.00^{\prime}$ & 5,035 & $\mathrm{NN}$ & 102 \\
\hline MUC & MTB-11 & 8 & 01.06 .2004 & $14^{\circ} 02.94^{\prime}$ & $130^{\circ} 04.73^{\prime}$ & 5,035 & $\mathrm{NN}$ & 110 \\
\hline $\mathrm{BC}$ & PL-1599/7 & CL1 & 31.05 .2004 & $14^{\circ} 01.96^{\prime}$ & $130^{\circ} 07.26^{\prime}$ & 4,979 & $\mathrm{~T}$ & 109 \\
\hline $\mathrm{BC}$ & PL-1599/7 & CL2 & 31.05 .2004 & $14^{\circ} 02.00^{\prime}$ & $130^{\circ} 07.24^{\prime}$ & 4,978 & $\mathrm{~T}$ & 106 \\
\hline $\mathrm{BC}$ & PL-1599/7 & CL3 & 31.05 .2004 & $14^{\circ} 02.03^{\prime}$ & $130^{\circ} 07.23^{\prime}$ & 4,978 & $\mathrm{~T}$ & 128 \\
\hline $\mathrm{BC}$ & PL-1599/7 & CL4 & 31.05 .2004 & $14^{\circ} 02.04^{\prime}$ & $130^{\circ} 07.22^{\prime}$ & 4,977 & $\mathrm{~T}$ & 120 \\
\hline $\mathrm{BC}$ & PL-1599/7 & CL5 & 31.05 .2004 & $14^{\circ} 02.15^{\prime}$ & $130^{\circ} 07.16^{\prime}$ & 4,980 & $\mathrm{~T}$ & 119 \\
\hline $\mathrm{BC}$ & PL-1599/7 & CL6 & 31.05 .2004 & $14^{\circ} 02.12^{\prime}$ & $130^{\circ} 07.17^{\prime}$ & 4,980 & $\mathrm{~T}$ & $-* *$ \\
\hline $\mathrm{BC}$ & PL-1599/7 & CL7 & 31.05 .2004 & $14^{\circ} 02.10^{\prime}$ & $130^{\circ} 07.19^{\prime}$ & 4,978 & $\mathrm{~T}$ & _** \\
\hline $\mathrm{BC}$ & PL-1599/7 & CL8 & 31.05 .2004 & $14^{\circ} 02.09^{\prime}$ & $130^{\circ} 07.19^{\prime}$ & 4,978 & $\mathrm{~T}$ & _** \\
\hline
\end{tabular}

* qualitative sample

** Only data on total nematode density were used 
Table 2. The maximum correlations (maximum Spearman's $\rho$ correlation coefficient) and the significance ( $p$-levels) of the relative abundance of some nematode taxa (selected by the BEST procedure) and the sampling pattern at the nodule-bearing site. The $H_{0}$ hypothesis is no correlation.

\begin{tabular}{|c|c|c|c|c|}
\hline \multirow[t]{2}{*}{$\begin{array}{c}\text { Taxonomic } \\
\text { level }\end{array}$} & \multicolumn{2}{|c|}{$\begin{array}{l}\text { Maximum correlation with } \\
\text { sample pattern (distance } \\
\text { between sampling points) }\end{array}$} & \multicolumn{2}{|c|}{$\begin{array}{l}\text { Maximum correlation with } \\
\text { spatial arrangement of } \\
\text { stations (latitude and } \\
\text { longitude) }\end{array}$} \\
\hline & Maximum $\rho$ & $p$ & Maximum $\rho$ & $p$ \\
\hline Species & 0.918 & 0.358 & 0.508 & 0.066 \\
\hline Genus & 0.921 & 0.188 & 0.307 & 0.159 \\
\hline Family & 0.780 & 0.303 & 0.405 & 0.100 \\
\hline
\end{tabular}


Table 3. The significance ( $p$-levels) of the correlation between the spatial arrangement of the stations from the nodule-bearing site and parameters of their nematode assemblages. The $H_{0}$ hypothesis is no correlation.

\begin{tabular}{ccc}
\hline Parameters & Latitude & Longitude \\
\hline Total density & 0.399 & 0.488 \\
Taxonomic diversity indices & & \\
$\Delta$ & 0.551 & 0.475 \\
$\Delta^{*}$ & 0.685 & 0.641 \\
Diversity indices at species level & & \\
$D$ & 0.585 & 0.541 \\
$J^{\prime}$ & 0.235 & 0.688 \\
$E S(51)$ & 0.511 & 0.761 \\
$H^{\prime}$ & 0.854 & 0.456 \\
$D$ & & \\
$J^{\prime}$ & 0.878 & 0.321 \\
$E G(51)$ & 0.605 & 0.469 \\
$H^{\prime}$ & 0.619 & 0.410 \\
$D$ & 0.870 & 0.250 \\
$D$ & & \\
$J^{\prime}$ & 0.448 & 0.846 \\
$E F(51)$ & 0.093 & 0.393 \\
$H^{\prime}$ & 0.180 & 0.898 \\
Diversity indicersity indices at family level level & 0.079 & 0.543 \\
\hline
\end{tabular}


Table 4. A list of families, genera, and number of species found within the track (582 nematode specimens were examined).

\begin{tabular}{llcllc}
\hline \multicolumn{1}{c}{ Family } & \multicolumn{1}{c}{ Genus } & $\begin{array}{c}\text { Number of } \\
\text { species }\end{array}$ & \multicolumn{1}{c}{ Family } & \multicolumn{1}{c}{ Genus } & $\begin{array}{c}\text { Number of } \\
\text { species }\end{array}$ \\
\hline Aegialolaimidae & Aegialolaimus & 3 & Linhomoeidae & Disconema & 1 \\
Anticomidae & Anticoma & 3 & & Terschellingia & 2 \\
Camacolaimidae & Camacolaimus & 3 & Microlaimidae & Microlaimus & 3 \\
Chromadoridae & Acantholaimus & 10 & Monhysteridae & Thalassomonhystera & 24 \\
& Chromadora & 1 & Oncholaimidae & Oncholaimus & 2 \\
& Chromadorina & 1 & & Phylloncholaimus & 1 \\
& Chromadorita & 1 & & Viscosia & 1 \\
& Endelophos & 1 & Oxystominidae & Halalaimus & 6 \\
& Euchromadora & 3 & & Litinium & 1 \\
& Innocuonema & 2 & & Oxystomina & 1 \\
Comesomatidae & Prochromadorella & 1 & Sphaerolaimidae & Subshaerolaimus & 1 \\
Cyartonematidae & Cyartonema & 3 & Tarvaidae & Tarvaia & 1 \\
Cyatholaimidae & Paracanthonchus & 3 & Thoracostomopsidae & Paramesacanthion & 1 \\
Desmodoridae & Chromaspirinia & 1 & Tripyloididae & Bathylaimus & 1 \\
& Desmodora & 3 & & Xmphimonhystrella & 1 \\
Desmoscolecidae & Desmoscolex & 7 & & Capsula & 1 \\
& Tricoma & 4 & & Daptonema & 2 \\
Diplopeltidae & Diplopeltula & 2 & & Elzalia & 1 \\
& Southerniella & 1 & & Enchonema & 3 \\
Draconematidae & Eudraconema & 1 & & Manganonema & 8 \\
Enchelidiidae & Bathyeurystomina & 1 & & Marisalbinema & 7 \\
& Eurystomina & 2 & & Metadesmolaimus & 1 \\
Ironidae & Syringolaimus & 3 & & Paramonhystera & 1 \\
Leptolaimidae & Antomicron & 1 & & Theristus & 4 \\
& Leptolaimus & 1 & & & \\
\hline & & & & \\
\hline
\end{tabular}


Table 5. The 10 most abundant taxa at species, genus, and family levels in the 26-year-old dredging track. Abbreviations: A.r.a.: average relative abundance; A.s.: average similarity.

\begin{tabular}{|c|c|c|c|c|c|}
\hline \multicolumn{2}{|l|}{ Species level (A.s.=34.2\%) } & \multicolumn{2}{|c|}{ Genus level (A.s.= 62.3\%) } & \multicolumn{2}{|c|}{$\begin{array}{l}\text { Family level (A.s.= } \\
71.8 \% \text { ) }\end{array}$} \\
\hline Taxon & $\begin{array}{l}\text { A.r.a. } \\
\text { (\%) }\end{array}$ & Taxon & $\begin{array}{l}\text { A.r.a. } \\
\text { (\%) }\end{array}$ & Taxon & $\begin{array}{l}\text { A.r.a. } \\
\text { (\%) }\end{array}$ \\
\hline Theristus discolensis & 12.4 & Thalassomonhystera & 34.4 & Monhysteridae & 34.4 \\
\hline Oncholaimus sp. 3 & 12.2 & Theristus & 11.6 & Xyalidae & 21.7 \\
\hline Thalassomonhystera sp. 19 & 9.0 & Oncholaimus & 10.7 & Chromadoridae & 11.4 \\
\hline Thalassomonhystera sp. 25 & 7.4 & Acantholaimus & 6.8 & Oncholaimidae & 11.0 \\
\hline Thalassomonhystera sp. 3 & 5.4 & Manganonema & 3.0 & Oxystominidae & 3.0 \\
\hline Thalassomonhystera sp. 10 & 2.4 & Halalaimus & 2.6 & Desmoscolecidae & 2.7 \\
\hline Thalassomonhystera sp. 21 & 2.4 & Enchonema & 2.6 & Ironidae & 1.6 \\
\hline Euchromadora sp. 1 & 2.0 & Euchromadora & 2.4 & Desmodoridae & 1.4 \\
\hline Acantholaimus angustus & 1.8 & Marisalbinema & 1.6 & Microlaimidae & 1.2 \\
\hline Enchonema sp. 1 & 1.4 & Desmoscolex & 1.5 & Aegialolaimidae & 1.0 \\
\hline
\end{tabular}


Table 6. Pairwise one-way ANOSIM-test $(p)$ for the differences in the composition of nematode assemblages from the nodule site (NB), the nodule-free site (NN), and the 26-yearold dredging track (T). The $H_{0}$ hypothesis is no difference between groups. Relative abundances were used, with no transformation.

\begin{tabular}{ccc}
\hline Taxon rank & $\begin{array}{c}\text { Compared pairs } \\
\text { T vs. NF }\end{array}$ & T vs. N \\
\hline Cosine similarity & & \\
Species level & $0.003^{*}$ & $0.002^{*}$ \\
Genus level & $0.002^{*}$ & $0.001^{*}$ \\
Family level & $0.007^{*}$ & $0.002^{*}$ \\
Bray-Curtis similarity & & \\
Species level & $0.001^{*}$ & $0.001^{*}$ \\
Genus level & $0.000^{*}$ & $0.001^{*}$ \\
Family level & $0.001^{*}$ & $0.000^{*}$ \\
\hline
\end{tabular}

*Difference is statistically significant at significance level 0.01 .

**Difference is statistically significant at significance level 0.05 . 
Table 7. The 5 taxa at species, genus, and family levels making the most contribution to dissimilarity (according to SIMPER test) between nematode assemblages from the track and adjacent intact sites. $\mathrm{NB}=$ nodule area, $\mathrm{NN}=$ nodule-free area, and $\mathrm{T}=26$-year-old dredging track. Abbreviations: A.r.a.: average relative abundance; A.d.: contribution to the average dissimilarity.

\begin{tabular}{|c|c|c|c|c|c|c|c|}
\hline \multicolumn{4}{|c|}{ Between $\mathrm{N}$ and $\mathrm{T}$ sites (A.d. $=78.9 \%$ ) } & \multicolumn{4}{|c|}{ Between NF and T sites (A.d. $=74.8 \%$ ) } \\
\hline \multirow{2}{*}{ Taxon } & \multicolumn{2}{|c|}{ A.r.a., $\%$} & \multirow{2}{*}{$\begin{array}{c}\text { A.d, } \\
\%\end{array}$} & \multirow{2}{*}{ Taxon } & \multicolumn{2}{|c|}{ A.r.a., $\%$} & \multirow{2}{*}{$\underset{\%}{\text { A.d, }}$} \\
\hline & NB & $\mathrm{T}$ & & & $\mathrm{NN}$ & $\mathrm{T}$ & \\
\hline Species level & & & & Species level & & & \\
\hline Oncholaimus sp. 3 & 0 & 12.2 & 5.7 & Oncholaimus sp. 3 & 0.3 & 12.2 & 5.8 \\
\hline Thalassomonhystera sp. 19 & 0.3 & 9.0 & 4.2 & Thalassomonhystera sp. 19 & 0.6 & 9.0 & 4.1 \\
\hline Thalassomonhystera sp. 3 & 11.9 & 5.4 & 3.7 & Thalassomonhystera sp. 25 & 0 & 7.4 & 3.5 \\
\hline Thalassomonhystera sp. 25 & 0 & 7.4 & 3.5 & Theristus discolensis & 10.9 & 12.4 & 3.0 \\
\hline Theristus discolensis & 6.1 & 12.4 & 3.4 & Thalassomonhystera sp. 3 & 7.3 & 5.4 & 2.1 \\
\hline Genus level & & & & Genus level & & & \\
\hline Thalassomonhystera & 22.7 & 34.4 & 7.1 & Thalassomonhystera & 20.6 & 34.4 & 8.1 \\
\hline Oncholaimus & 0.2 & 10.7 & 5.3 & Oncholaimus & 0.9 & 10.7 & 5.0 \\
\hline Acantholaimus & 16.9 & 6.8 & 5.0 & Acantholaimus & 14.5 & 6.8 & 3.8 \\
\hline Theristus & 6.9 & 11.6 & 3.0 & Theristus & 12.1 & 11.6 & 2.9 \\
\hline Desmoscolex & 5.3 & 1.5 & 2.2 & Marisalbinema & 4.9 & 1.6 & 1.8 \\
\hline Family level & & & & Family level & & & \\
\hline Monhysteridae & 22.7 & 34.4 & 7.1 & Monhysteridae & 20.6 & 34.4 & 8.1 \\
\hline Chromadoridae & 24.5 & 11.4 & 6.7 & Xyalidae & 27.3 & 21.7 & 5.0 \\
\hline Oncholaimidae & 0.6 & 11.0 & 5.2 & Oncholaimidae & 1.2 & 11.0 & 5.0 \\
\hline Xyalidae & 16.8 & 21.7 & 4.0 & Chromadoridae & 18.2 & 11.4 & 3.5 \\
\hline Desmoscolecidae & 8.4 & 2.7 & 3.2 & Desmoscolecidae & 6.8 & 2.7 & 2.1 \\
\hline
\end{tabular}


Table 8. Pairwise Student's $t$-test $(p)$ for the difference between diversity indices of the nodule area $(\mathrm{NB})$, the nodule-free area $(\mathrm{NN})$, and the 26-year-old dredging track $(\mathrm{T})$. The $H_{0}$ hypothesis is that both compared sites have equal mean values. All index values were lognormalized.

\begin{tabular}{|c|c|c|c|c|c|c|}
\hline \multirow{2}{*}{ Index } & \multicolumn{2}{|c|}{ Species level } & \multicolumn{2}{|c|}{ Genus level } & \multicolumn{2}{|c|}{ Family level } \\
\hline & vs. $\Gamma$ & T vs. NB & $\Gamma$ vs. NN & T vs. NB & T vs. NN & T vs. NB \\
\hline$d$ & & & & & 0 . & \\
\hline$J^{\prime}$ & & & & & ** & 0.0 \\
\hline$(51) *$ & $0.000^{\circ}$ & 0.00 & 0.00 & $3 *$ & $0.213 * *$ & $0.264 * *$ \\
\hline ? & $0.005 *$ & $0.003 *$ & $0.002 *$ & $0.209 *$ & $0.101 * *$ & $0.125 * *$ \\
\hline
\end{tabular}

*Difference is statistically significant at significance level 0.01 .

**Difference is statistically significant at significance level 0.05 .

*** $E T(51)=$ expected number of taxa (at species, or genus, or family levels) per 51 individuals. 
Table 9. Pairwise Student's $t$-test $(p)$ for differences between taxonomic diversity indices of the nodule area $(\mathrm{N})$, the nodule-free area $(\mathrm{NF})$, and the 26-year-old dredging track (T). The $H_{0}$ hypothesis is that both compared sites have equal mean values. All index values were lognormalized.

\begin{tabular}{cccc}
\hline Index & NB vs. NN & T vs. NN & T vs. NB \\
\hline$\Delta$ (average taxonomic diversity) & 0.348 & $0.005^{*}$ & $0.005^{*}$ \\
$\Delta^{*}$ (average taxonomic distinctiveness) & 0.138 & $0.049^{* *}$ & $0.041^{* *}$ \\
\hline
\end{tabular}

*Difference is statistically significant at significance level 0.01 .

**Difference is statistically significant at significance level 0.05 . 
Table 10. A comparison of disturbance methods, recovery of the disturbed areas, and recovery (in comparison with the reference, i.e., adjacent undisturbed site) of nematode assemblages in three deep-sea disturbance experiments.

\begin{tabular}{|c|c|c|c|}
\hline \multicolumn{4}{|l|}{ Disturbance experiment } \\
\hline Name, year & OMCO, 1978 & IOM BIE, 1995 & DISCOL, 1989 \\
\hline Region & $\begin{array}{c}\text { Central part of CCFZ, } \\
\text { Pacific }\end{array}$ & $\begin{array}{c}\text { Eastern part of CCFZ, } \\
\text { Pacific }\end{array}$ & Peru Basin, Pacific \\
\hline Depth, m & $\sim 5,000$ & $\sim 4,300$ & $\sim 4,100$ \\
\hline Disturbance gear & $\begin{array}{l}\text { Self-propelled miner with } \\
\text { two Archimedean screws }\end{array}$ & $\begin{array}{l}\text { Passively towed, two- } \\
\text { runner, sled-type disturber }\end{array}$ & $\begin{array}{l}\text { Passively towed, } \\
\text { "plough-harrow"-like } \\
\text { disturber }\end{array}$ \\
\hline Area of disturbance & ? (at least several tracks) & $\begin{array}{c}\sim 1800 \mathrm{~m}^{2}(14 \text { tracks }) \text { of } \\
\text { total experimental field } 3 \\
\mathrm{~km}^{2}\end{array}$ & $\begin{array}{l}\sim 2 \mathrm{~km}^{2} \text { of total } \\
\text { experimental field } 10.8 \\
\mathrm{~km}^{2}\end{array}$ \\
\hline Width of track, m & $\sim 1.5$ & $\sim 2.4$ & $\sim 8$ \\
\hline $\begin{array}{l}\text { Depth of disturbed } \\
\text { sediments, cm }\end{array}$ & $\sim 4$ & $-*$ & $10-15$ \\
\hline $\begin{array}{l}\text { Impact on superficial } \\
\text { soft sediment layer }\end{array}$ & $\begin{array}{l}\text { Completely released into } \\
\text { water column }\end{array}$ & $\begin{array}{l}\text { Completely released into } \\
\text { water column }\end{array}$ & $\begin{array}{l}\text { Stirred and partially } \\
\text { raised into water column }\end{array}$ \\
\hline Impact on nodules & Completely extracted & Not extracted & Stirred, but not extracted \\
\hline $\begin{array}{l}\text { Changes in habitat } \\
\text { heterogeneity after } \\
\text { disturbance }\end{array}$ & Decreased & Decreased & Increased \\
\hline \multicolumn{4}{|c|}{ Post-impact study, a comparison of the disturbed fields with adjacent, undisturbed fields } \\
\hline Year & 2004 & 1997 & 1996 \\
\hline $\begin{array}{l}\text { Time after } \\
\text { disturbance, years }\end{array}$ & 26 & 2 & 7 \\
\hline $\begin{array}{l}\text { Visible effects of } \\
\text { disturbance }\end{array}$ & Track looks fresh & $\begin{array}{l}\text { Track almost not visible, } \\
\text { enriched with } \\
\text { phytodetritus }\end{array}$ & $\begin{array}{l}\text { Track visible but having } \\
\text { fuzzy contours }\end{array}$ \\
\hline Sediment structure & Did not recover & Recovered & Did not recover \\
\hline $\begin{array}{l}\text { Nematode assemblage } \\
\text { structure at genus } \\
\text { level }\end{array}$ & Significant difference & Significant difference & No difference \\
\hline $\begin{array}{l}\text { Nematode assemblage } \\
\text { structure at family } \\
\text { level }\end{array}$ & Significant difference & $-*$ & Significant difference \\
\hline $\begin{array}{l}\text { Nematode diversity at } \\
\text { genus level }\end{array}$ & Decreased & Decreased & Decreased \\
\hline $\begin{array}{l}\text { Nematode diversity at } \\
\text { family level }\end{array}$ & Decreased & $-*$ & $-*$ \\
\hline $\begin{array}{l}\text { Total nematode } \\
\text { density }\end{array}$ & Decreased & No difference & Decreased \\
\hline References & $\begin{array}{l}\text { Present study; Chung (2005); } \\
\text { Khripounoff et al. (2006) }\end{array}$ & $\begin{array}{c}\text { Brockett (1994); } \\
\text { Radziejewska et al. } \\
\text { (2001a,b); Radziejewska } \\
\text { (2002) }\end{array}$ & $\begin{array}{c}\text { Vopel and Thiel (2001); } \\
\text { Borowsky (2001) }\end{array}$ \\
\hline
\end{tabular}

* No data available. 


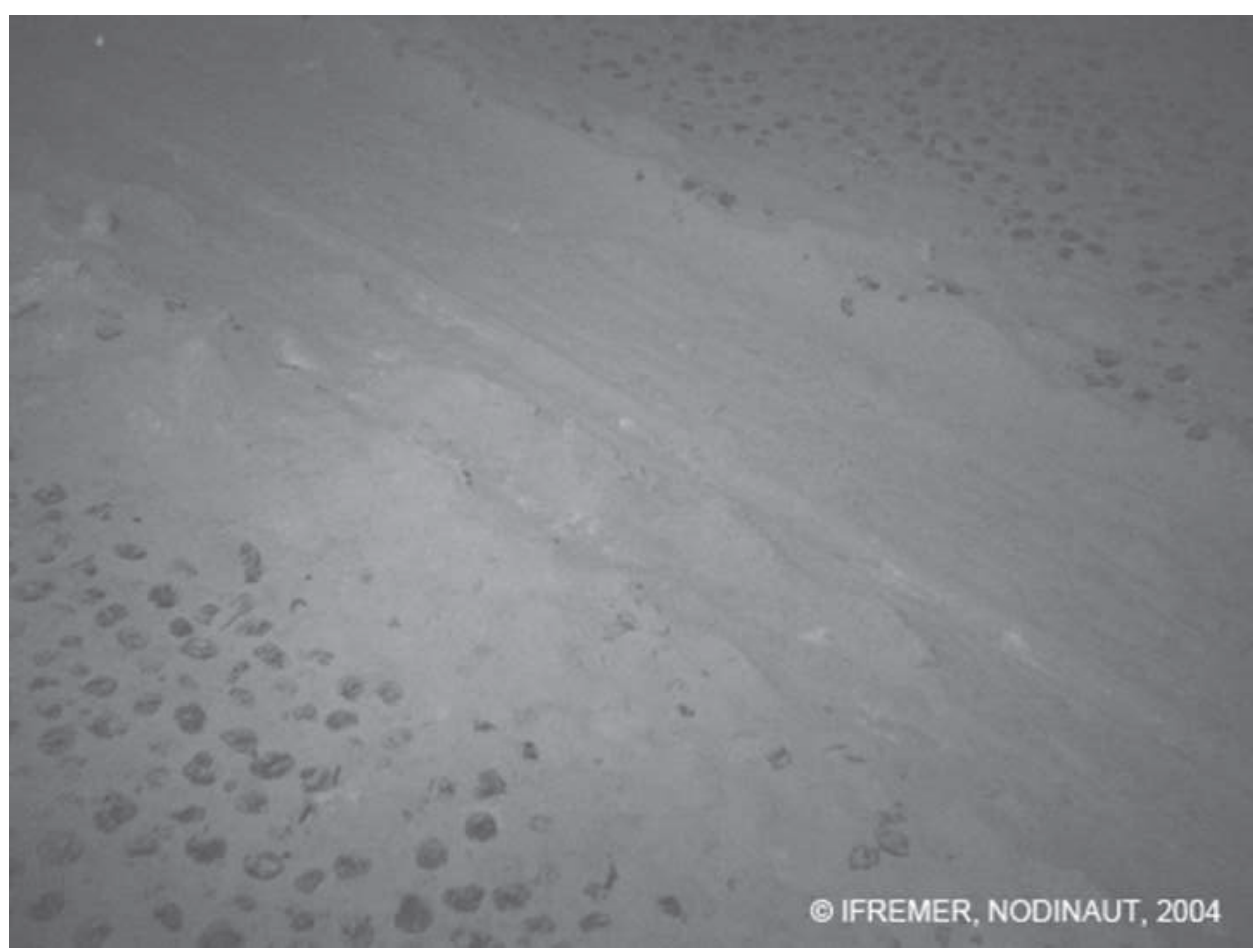




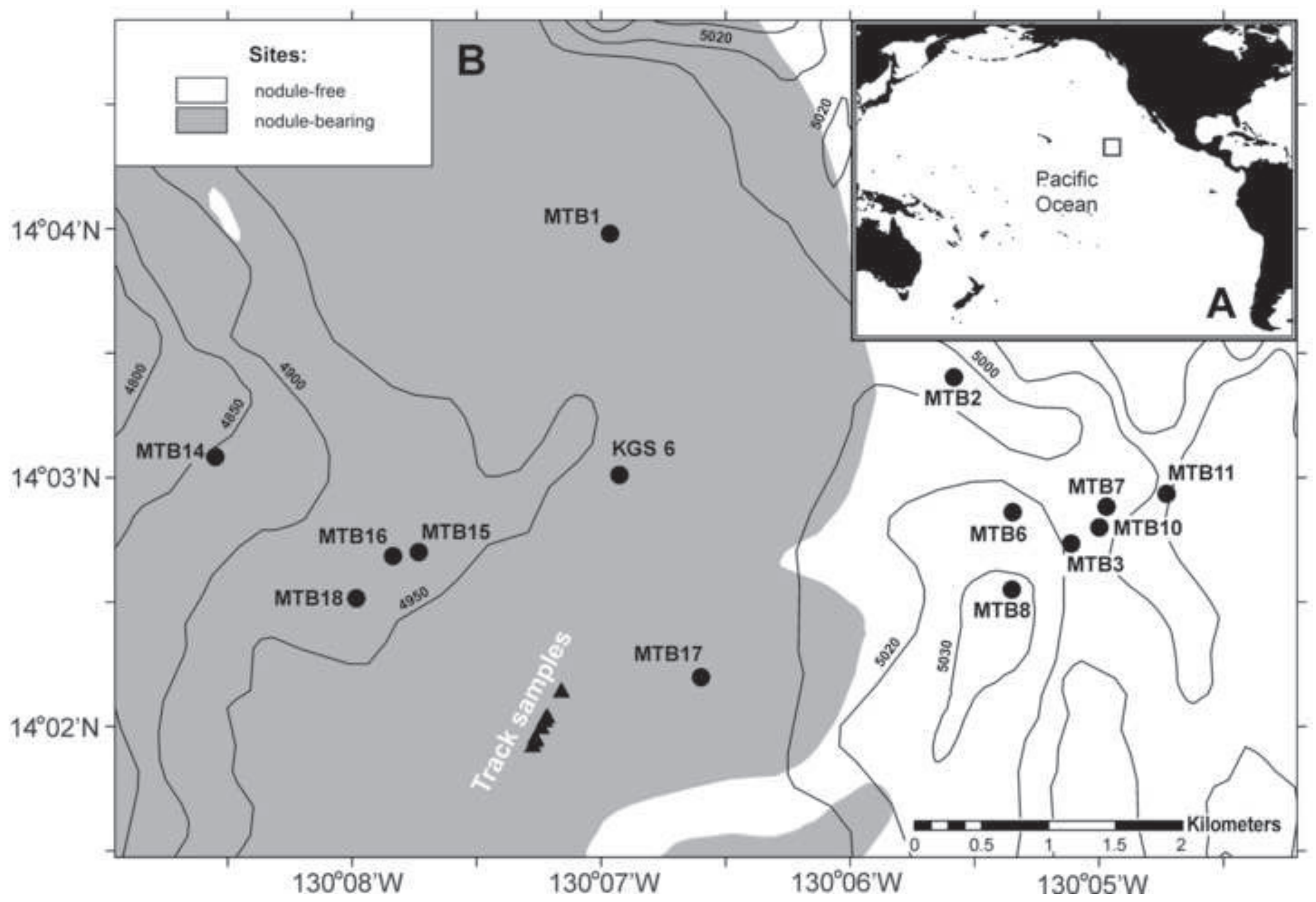


A

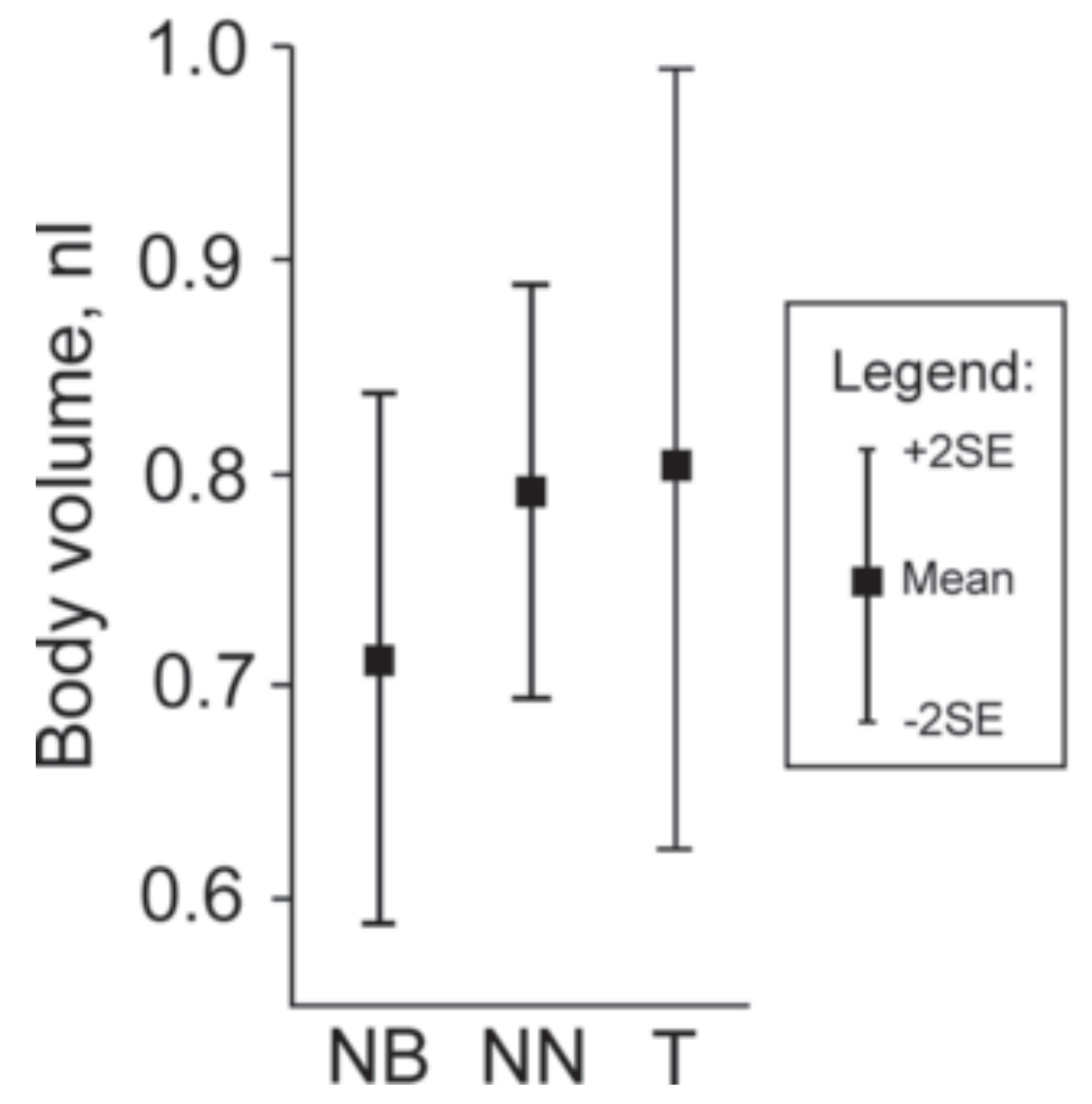

B

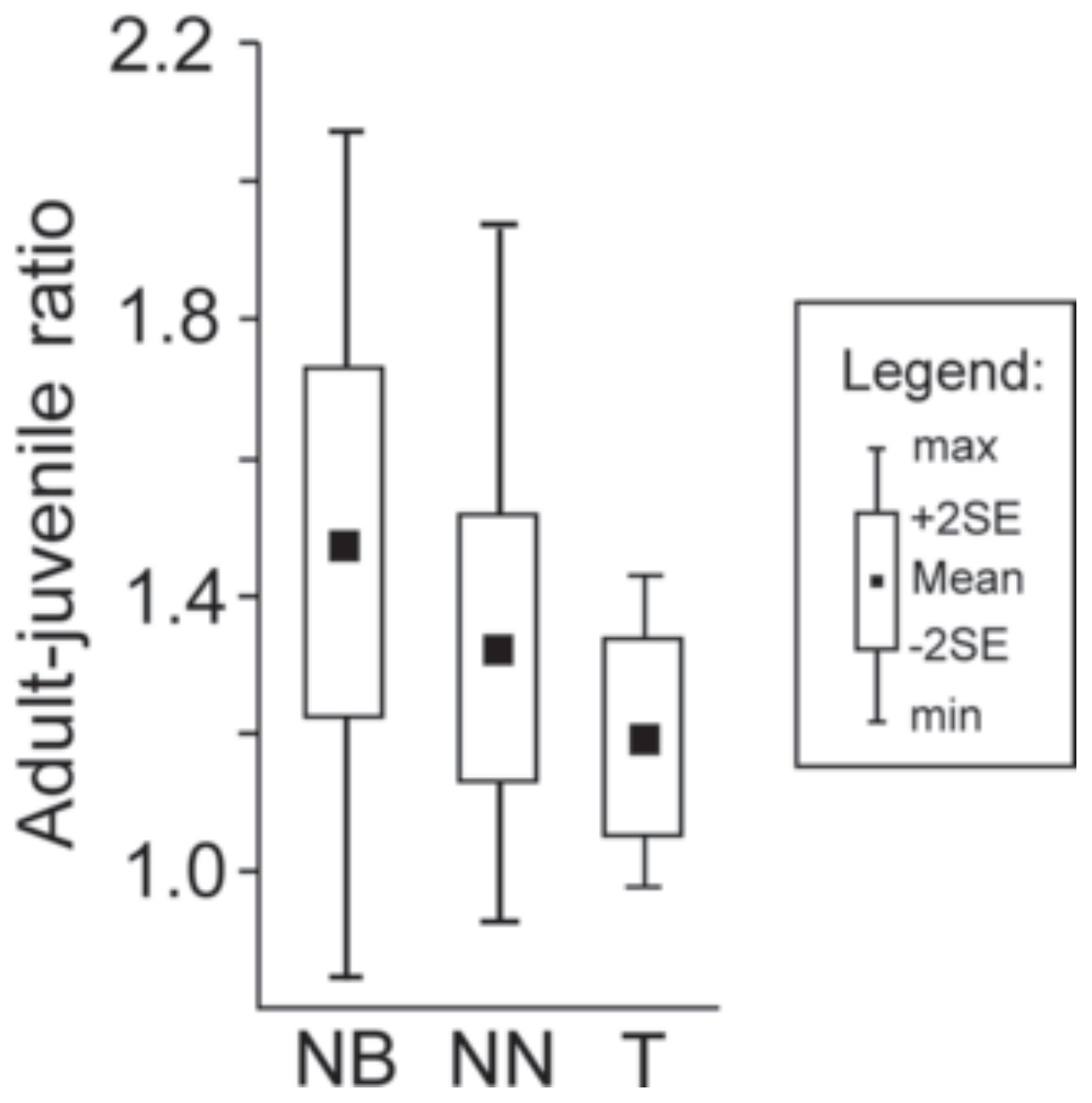




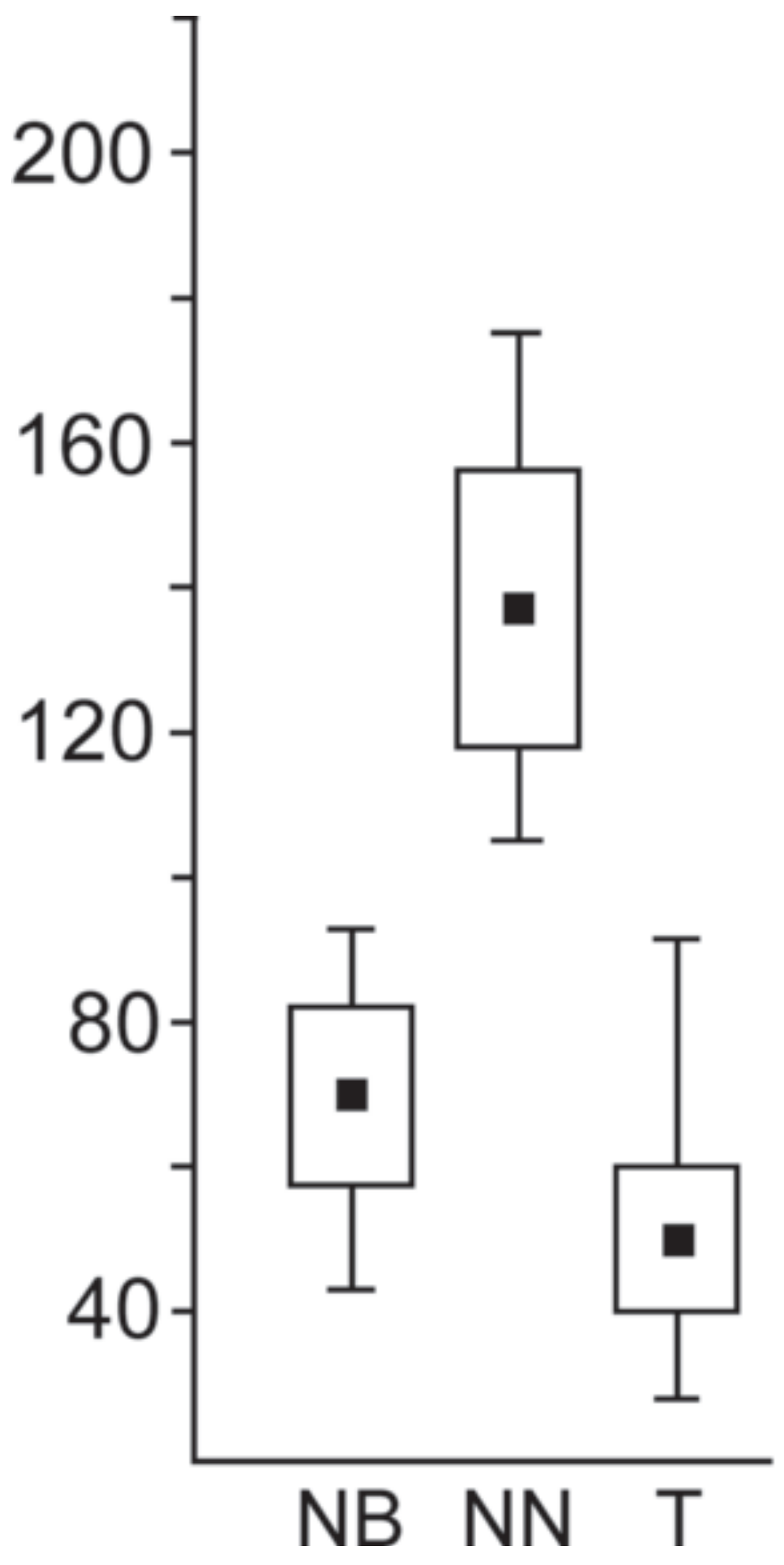

Legend:

T $\max$

$\square+2$ SE

- Mean

-2SE

$1 \min$ 


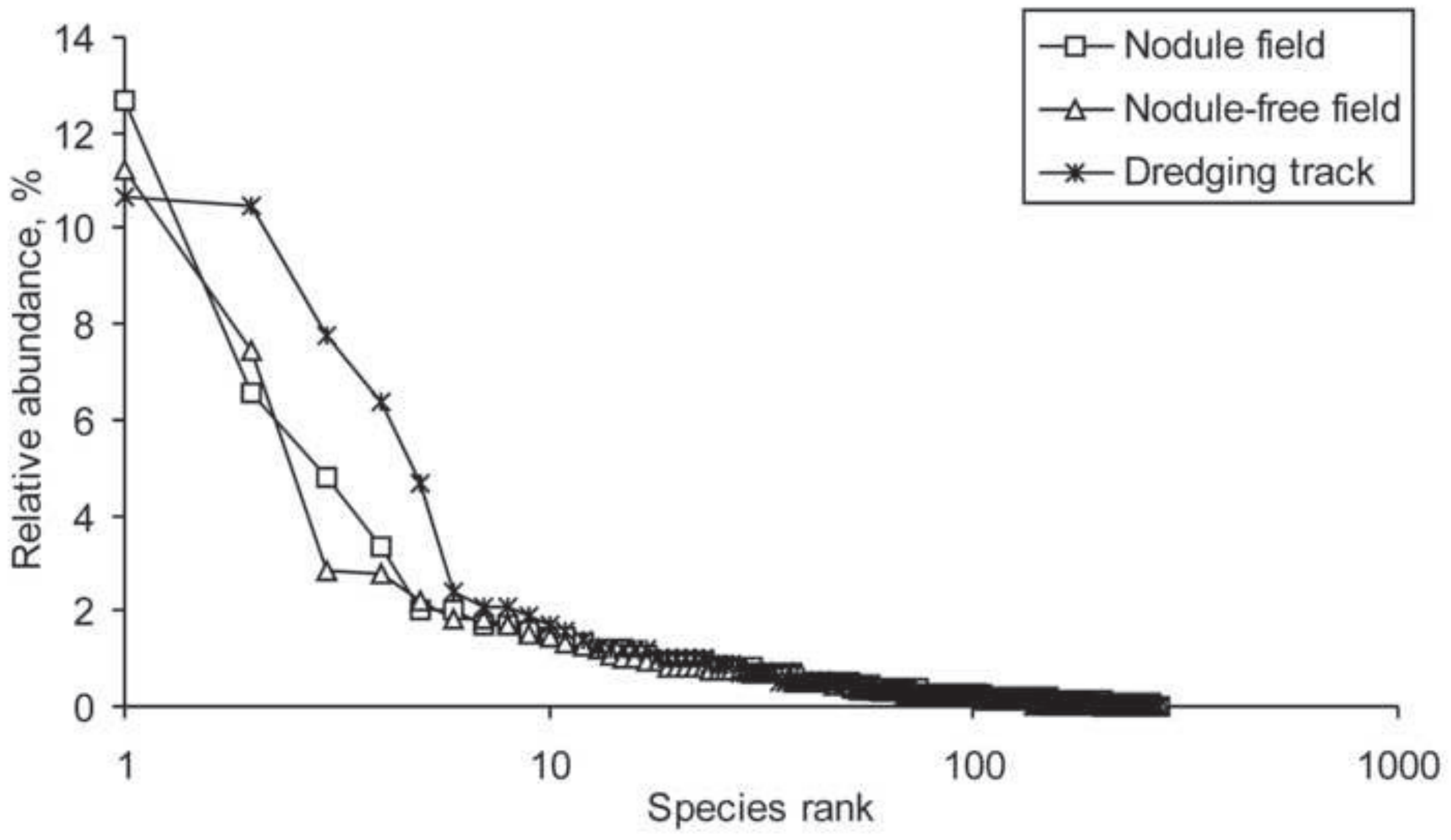




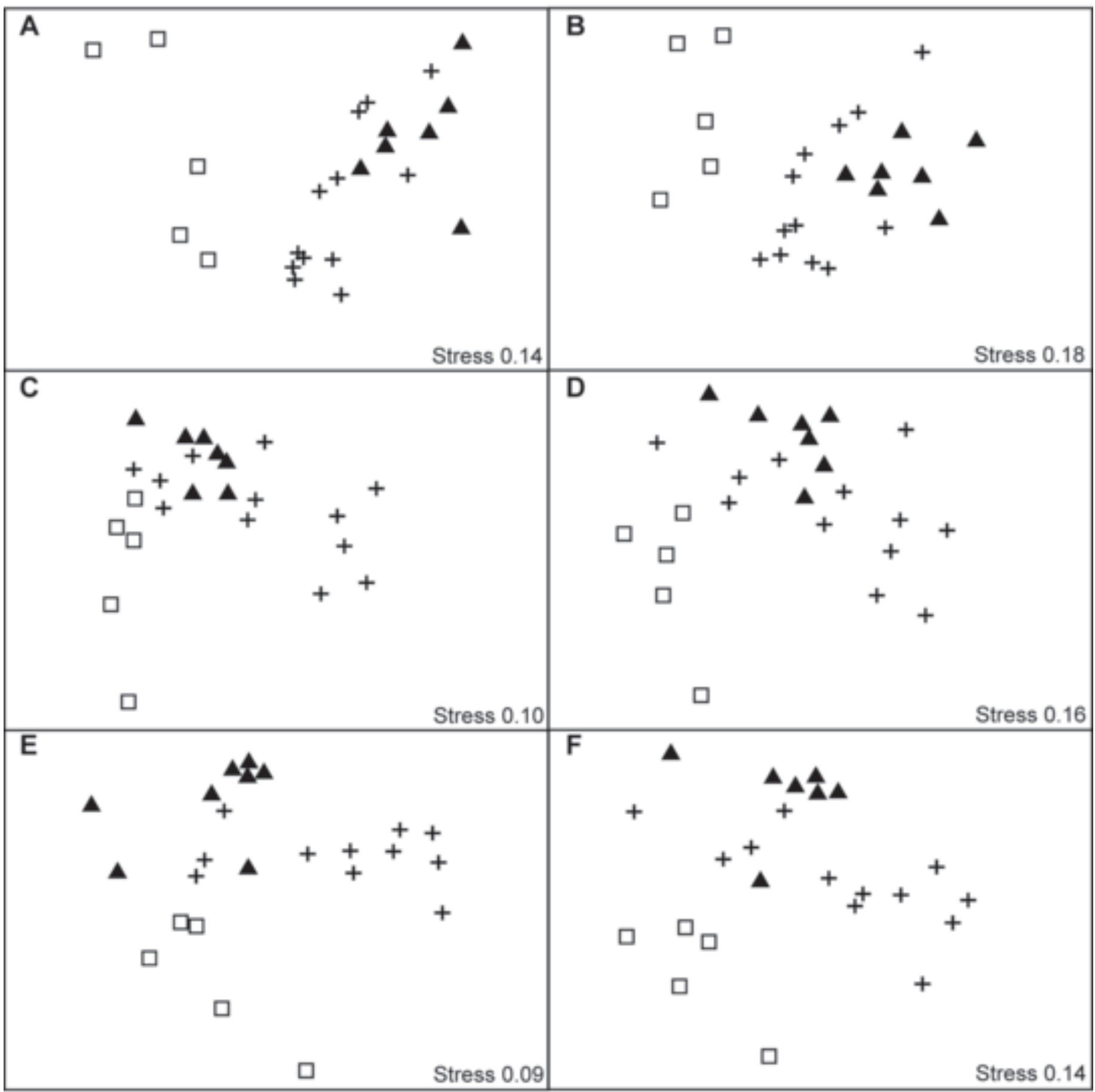


Spesies level

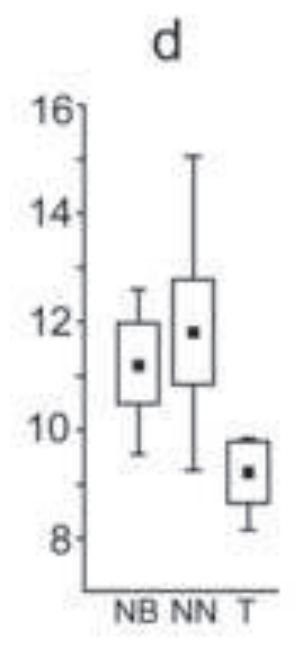

$\mathrm{J}$

$\mathrm{ES}(51)$

$\mathrm{H}^{\prime}$
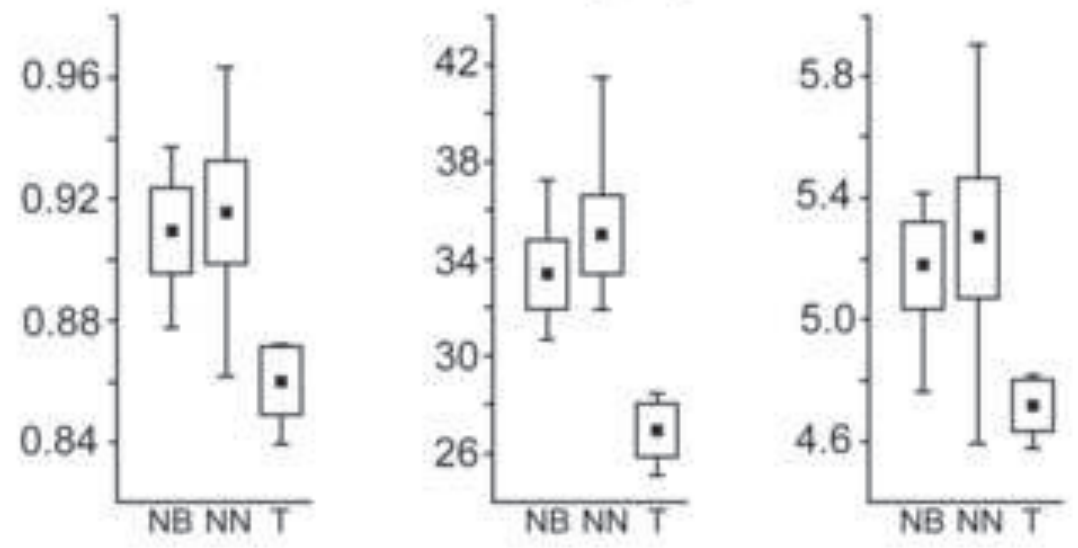

Genus level
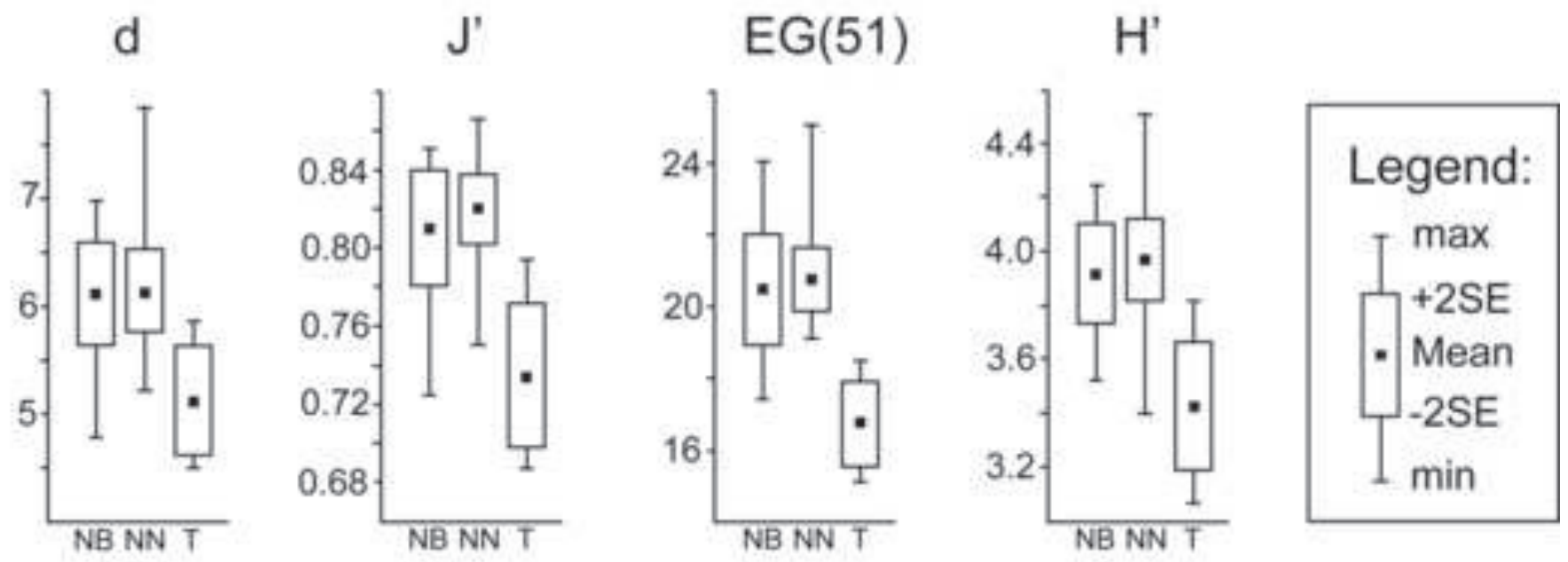

Family level

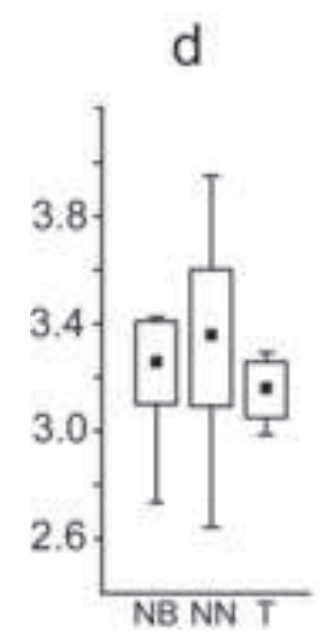

J'

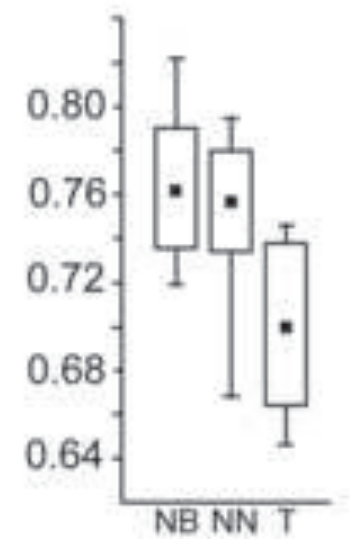

$E F(51)$

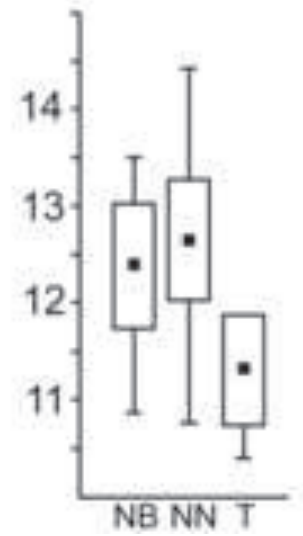

$\mathrm{H}^{\prime}$

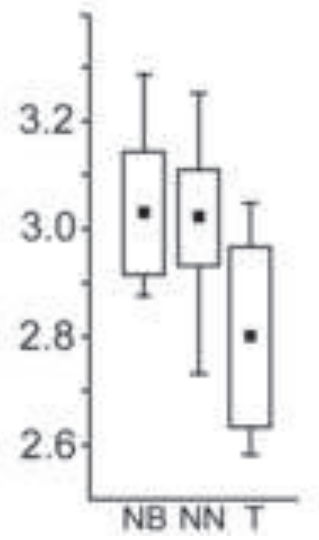


$\Delta$

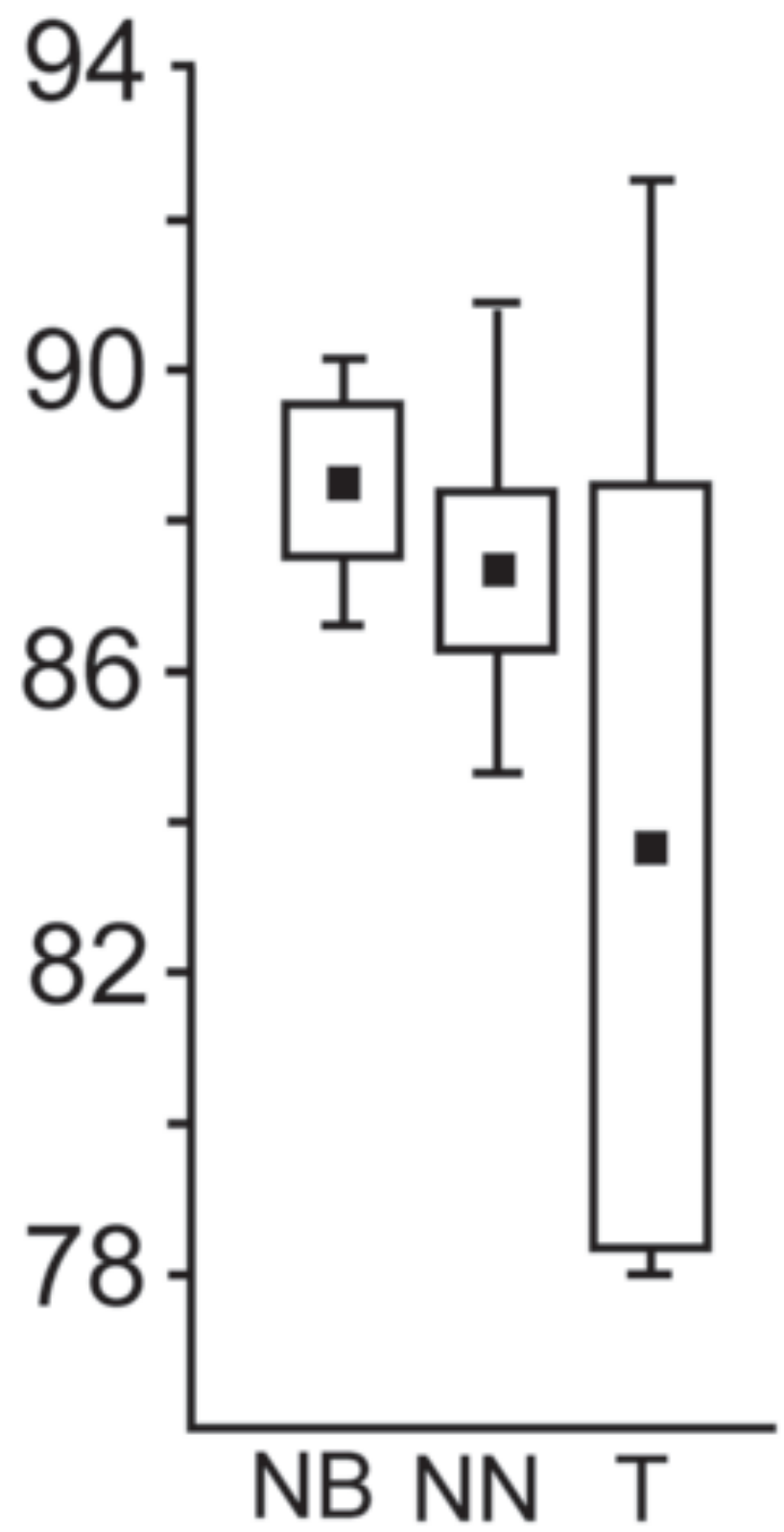

$\Delta^{*}$

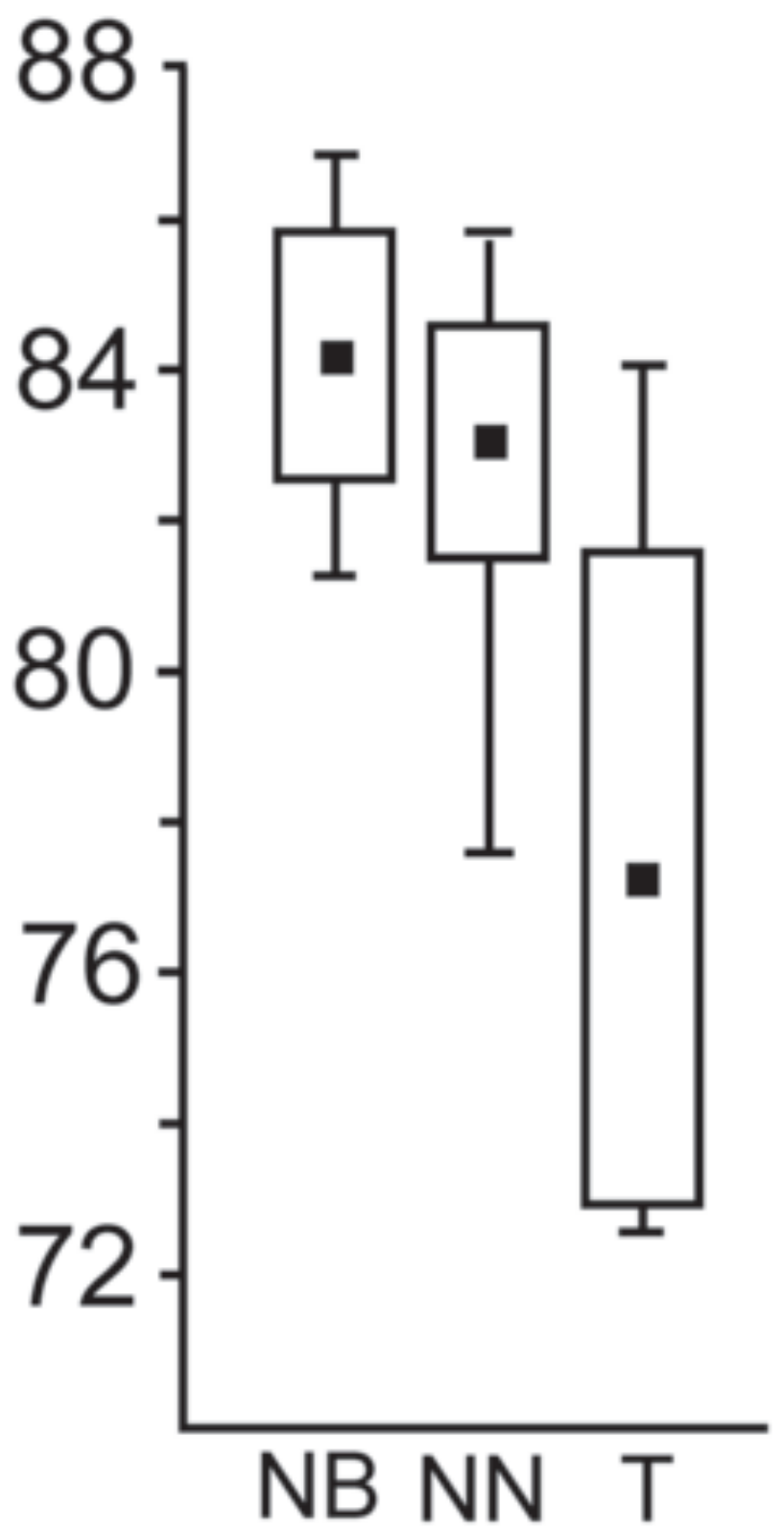

Legend:

$\mathrm{T} \max$

+2SE

- Mean

L-2SE

$1 \mathrm{~min}$ 


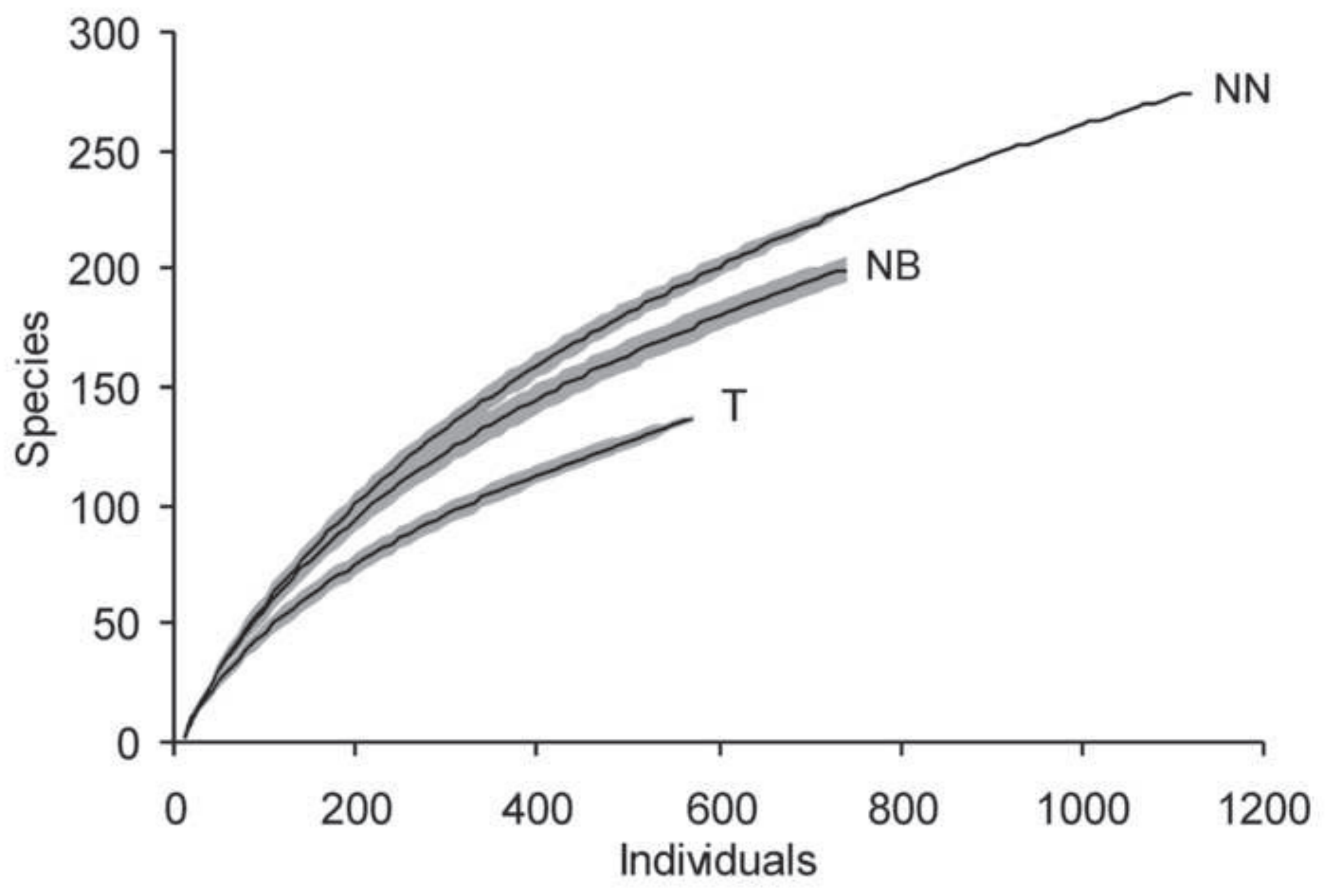

